\title{
Acute Coronary Syndromes (ACS)—Unravelling Biology to Identify New Therapies-The Microcirculation as a Frontier for New Therapies in ACS
}

\author{
Kaivan Vaidya ${ }^{1,2}$, Bradley Tucker ${ }^{2,3,4}$ (D), Sanjay Patel ${ }^{1,2,3}$ and Martin K. C. Ng 1,2,* \\ 1 Department of Cardiology, Royal Prince Alfred Hospital, Camperdown 2050, Australia; \\ kaivan.vaidya@gmail.com (K.V.); sanjay.patel599@gmail.com (S.P.) \\ 2 Sydney Medical School, University of Sydney, Camperdown 2050, Australia; b.tucker@student.unsw.edu.au \\ 3 Heart Research Institute, Newtown 2042, Australia \\ 4 School of Medical Sciences, University of New South Wales, Kensington 2052, Australia \\ * Correspondence: martin.ng@sydney.edu.au; Tel.: +61-2-95156111
}

Citation: Vaidya, K.; Tucker, B.;

Patel, S.; Ng, M.K.C. Acute Coronary Syndromes (ACS)-Unravelling Biology to Identify New TherapiesThe Microcirculation as a Frontier for New Therapies in ACS. Cells 2021, 10, 2188. https://doi.org/10.3390/ cells10092188

Academic Editor: Giulio Ceolotto

Received: 21 July 2021

Accepted: 23 August 2021

Published: 25 August 2021

Publisher's Note: MDPI stays neutral with regard to jurisdictional claims in published maps and institutional affiliations.

Copyright: (c) 2021 by the authors. Licensee MDPI, Basel, Switzerland. This article is an open access article distributed under the terms and conditions of the Creative Commons Attribution (CC BY) license (https:// creativecommons.org/licenses/by/ $4.0 /)$.

\begin{abstract}
In acute coronary syndrome (ACS) patients, restoring epicardial culprit vessel patency and flow with percutaneous coronary intervention or coronary artery bypass grafting has been the mainstay of treatment for decades. However, there is an emerging understanding of the crucial role of coronary microcirculation in predicting infarct burden and subsequent left ventricular remodelling, and the prognostic significance of coronary microvascular obstruction (MVO) in mortality and morbidity. This review will elucidate the multifaceted and interconnected pathophysiological processes which underpin MVO in ACS, and the various diagnostic modalities as well as challenges, with a particular focus on the invasive but specific and reproducible index of microcirculatory resistance (IMR). Unfortunately, a multitude of purported therapeutic strategies to address this unmet need in cardiovascular care, outlined in this review, have so far been disappointing with conflicting results and a lack of hard clinical end-point benefit. There are however a number of exciting and novel future prospects in this field that will be evaluated over the coming years in large adequately powered clinical trials, and this review will briefly appraise these.
\end{abstract}

Keywords: microvascular obstruction; acute coronary syndrome; index of microcirculatory resistance; percutaneous coronary intervention; myocardial infarction

\section{Introduction}

In patients presenting with an acute coronary syndrome (ACS), protective mechanical and pharmacological interventions are aimed at infarct size reduction, reperfusion of viable myocardium, and attenuation of necrosis leading to heart failure [1]. Historically, the focus on ACS treatment has been on the epicardial coronary artery culprit lesion. In particular, primary percutaneous coronary intervention (PCI) is now the preferred reperfusion strategy for acute ST-elevation myocardial infarction (STEMI) and aims to restore patency of the epicardial infarct-related artery and achieve reperfusion to limit the extent of myocardial damage [2,3].

Advances in the treatment of STEMI patients has led to a progressive decline in mortality over several decades, with one-year cardiac mortality after primary PCI at 7-8\% [4]. However, in approximately 50\% of STEMI patients, effective reperfusion does not occur despite timely epicardial recanalisation due to the occurrence of coronary microvascular obstruction (MVO), which is a critical determinant of adverse cardiovascular outcomes including mortality and heart failure hospitalisation [5-8]. MVO is a key independent predictor of adverse left ventricular (LV) remodelling and major adverse cardiovascular events (MACE) irrespective of infarct size. Moreover, MVO may be a more potent predictor of MACE than infarct size [7,9] or patency of the infarct-related epicardial artery [5]. In a study 
of 249 STEMI patients over a median 6-year follow-up, those with CMR-demonstrated MVO had higher rates of MACE than those without $(54 \%$ vs. $9 \%, p<0.001)$ and MVO was the strongest predictor of MACE with incremental prognostic value over infarct size and LV ejection fraction [10].

The overwhelming evidence for the prognostic significance of MVO underpins the need for strategies to protect or restore coronary microcirculatory flow. To date, there has been a paucity of cardioprotective therapies targeting MVO. Moreover, the translation of potential strategies (such as reduction in thrombus burden, conditioning, and administration of anti-thrombotic or vasodilatory drugs) into improved clinical outcomes has been disappointing due to difficulties with clinical trial design and a lack of hard clinical end-point benefit [11]. In this review, we provide a detailed summary of the pathogenesis of MVO, diagnosis of MVO during evolving ACS, potential therapeutic strategies and their limitations, and an evaluation of future opportunities on the horizon to mitigate MVO in ACS patients.

\section{Pathogenesis of MVO}

MVO is defined as the inability to reperfuse the coronary microcirculation (microvessels $<200 \mu \mathrm{m}$ diameter) in a previously ischaemic myocardial territory, despite restoration of epicardial vessel patency. There are several interdependent mechanisms underlying MVO and myocardial injury (Figure 1), which are delineated below [1,2,11].

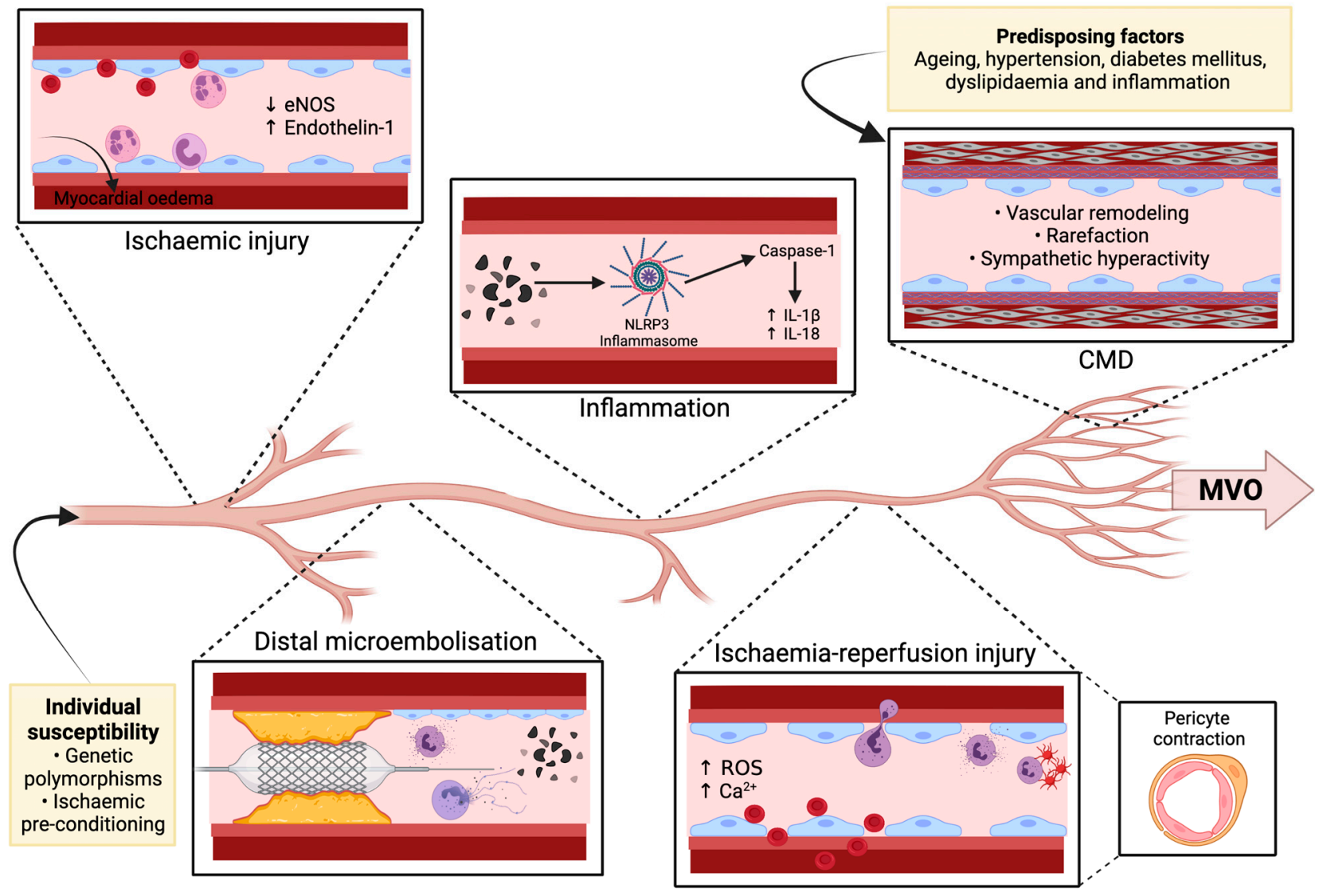

Figure 1. Pathophysiology of MVO. Various genetic polymorphisms and the absence of ischaemic pre-conditioning predispose coronary microcirculation to injury. Plaque disruption, whether spontaneous or PCI-induced, results in distal microembolisation of cellular debris and augmentation of the inflammatory cascade, particularly neutrophil activation. Ischaemic injury to the microcirculation causes endothelial damage and extravasation of erythrocytes and inflammatory cells, resulting in myocardial oedema and luminal narrowing. Moreover, ischaemic injury promotes vasoconstriction by decreasing eNOS release and increasing endothelin-1 release, further limiting microvascular flow. Triggered by inflammatory debris, the NLRP3 inflammasome activates caspase- 1 thereby mediating the cleavage of proIL-1b and proIL-18 into their 
active forms. Reperfusion after a prolonged ischaemic period further potentiates the inflammatory response by augmenting leukocyte recruitment, ROS generation, neutrophil-platelet aggregate formation, and calcium release. Ischaemia-reperfusion injury also induces pericyte contraction and intramyocardial haemorrhage which further limit microvascular flow. Increasing age, hypertension, diabetes mellitus, dyslipidaemia, and inflammation all predispose to CMD, which is characterised by perivascular fibrosis, smooth muscle cell and endothelial dysfunction, vascular remodelling, rarefaction, and sympathetic hyperactivity. These interdependent mechanisms form the underlying pathogenesis of MVO. Abbreviations: $\mathrm{Ca}^{2+}, \mathrm{Calcium}$; CMD, Coronary microvascular dysfunction; eNOS, Endothelial nitric oxide synthase; MVO, Microvascular obstruction; ROS, Reactive oxygen species.

\subsection{Pre-Existing Coronary Microvascular Dysfunction}

Coronary microvascular dysfunction (CMD) is a mismatch of myocardial blood supply and oxygen consumption due to coronary microvessel dysfunction and can occur with or without obstructive coronary artery disease (CAD) and/or myocardial diseases (Table 1). The key pathogenic mechanisms driving CMD include vascular remodelling and rarefaction, perivascular fibrosis, and functional alterations such as sympathetic activation, endothelial dysfunction or smooth muscle cell dysfunction [12,13].

Table 1. Classification of CMD [12].

\begin{tabular}{|c|c|c|}
\hline Type & Clinical Setting & Pathogenesis \\
\hline $\begin{array}{l}\text { 1-no myocardial diseases or obstructive } \\
\text { coronary artery disease }\end{array}$ & Microvascular angina & $\begin{array}{l}\text { Endothelial dysfunction } \\
\text { Smooth muscle cell dysfunction } \\
\text { Vascular remodeling }\end{array}$ \\
\hline 2-myocardial diseases & $\begin{array}{c}\text { Hypertrophic cardiomyopathy } \\
\text { Aortic stenosis } \\
\text { Dilated cardiomyopathy } \\
\text { Amyloidosis } \\
\text { Myocarditis }\end{array}$ & $\begin{array}{c}\text { Smooth muscle cell dysfunction } \\
\text { Vascular remodeling } \\
\text { Extramural compression }\end{array}$ \\
\hline 3 -obstructive coronary artery disease & $\begin{array}{l}\text { Stable angina or acute coronary } \\
\text { syndrome }\end{array}$ & $\begin{array}{l}\text { Endothelial dysfunction } \\
\text { Smooth muscle cell dysfunction } \\
\text { Luminal obstruction }\end{array}$ \\
\hline 4-iatrogenic & $\begin{array}{l}\text { Percutaneous coronary intervention } \\
\text { or coronary artery bypass grafting }\end{array}$ & $\begin{array}{l}\text { Luminal obstruction } \\
\text { Autonomic dysfunction }\end{array}$ \\
\hline
\end{tabular}

Pre-existing CMD is often present in ACS patients before their index event, which can result in an increased risk of significant $\mathrm{MVO}$ and poor cardiovascular outcomes. Furthermore, pre-existent CMD likely represents an important pathological contributor of MVO, as studies have demonstrated that coronary flow is attenuated by up to $50 \%$ in non-culprit arteries during acute myocardial infarction (AMI), both before and after primary PCI, suggesting global rather than regional myocardial microcirculatory dysfunction [14]. Indeed, pre-existing CMD has been shown to be a strong independent risk factor for peri-PCI myocardial infarction in stable coronary heart disease patients, indicating that pre-existing CMD is a critical determinant of susceptibility for further microvascular injury [15]. In particular, Type 1 CMD is associated with a multitude of risk factors, many of which predispose to ACS itself, and which modulate functional and structural microvascular alterations. These risk factors include ageing, hypertension, diabetes mellitus, insulin resistance, dyslipidaemia, and chronic inflammation $[1,2,12,13,16]$. Chronic hyperglycaemia and insulin resistance in particular have been associated with significantly reduced coronary vasodilator function [17]. Moreover, acute hyperglycaemia also predisposes to MVO and reperfusion injury by causing microvascular leucocyte plugging, increasing platelet procoagulability, and elevating free fatty acid levels which reduce endothelial-dependent vasodilatation [2,18]. Similarly, hypercholesterolaemia impairs vascular endothelial function and reactivity by a reduction in nitric oxide bioavailability, elevated oxidative stress, and a proinflammatory milieu [19]. 


\subsection{Individual Susceptibility}

Various genetic factors also play a role in modulating adenosine-induced vasodilatation and subsequent microcirculatory function. The 1976T.C polymorphism of the adenosine $2 \mathrm{~A}$ receptors gene is related to a higher prevalence of $\mathrm{MVO}$, and genetic variations in regions of the VEGFA and CDKN2B-AS1 genes have been associated with CMD. Patients with MVO also have a more compact fibrin network, suggesting a genetically mediated resistance to clot permeability and lysis [1,2]. Finally, another key factor determining individual susceptibility to MVO is the presence of ischaemic pre-conditioning (IPC) and its clinical correlate pre-infarction angina, which is protective for both the myocardium and the coronary microcirculation [20].

\subsection{Ischaemic Injury}

Ischaemic injury is a well-described mechanism for cardiomyocyte cell death, especially if the period of myocardial ischaemia lasts over $3 \mathrm{~h}$ in duration. Ischaemia to the microcirculation results in capillary damage, endothelial protrusions/blebs which occlude the capillary lumen, decreased endothelial nitric oxide synthase (eNOS) vasodilator release, and increased endothelin-1 vasoconstrictor release. Furthermore, ischaemia induces disruption of the endothelial glycocalyx barrier and destabilization of interendothelial cell junctions resulting in extravascular erythrocytes, adhesion and influx of inflammatory cells, and interstitial myocardial oedema which compresses capillaries and small arterioles, further reducing flow through these dysfunctional vessels in a vicious cycle $[1-3,16]$. If there is no reperfusion of the infarct-related artery, the eventual outcome is irreversible necrosis and complete $\mathrm{MVO}$ of the affected myocardial territory, although collateral circulation can be somewhat protective in this process.

\subsection{Ischaemia-Reperfusion Injury}

After a prolonged period of ischaemia, reperfusion of the affected region potentiates further injury to the microvasculature. Reperfusion stimulates reactive oxygen species (ROS) production by mitochondria, which subsequently results in increased membrane permeability, calcium overload, endothelial swelling, and cell disruption. An influx of leucocytes, platelets, and neutrophil-platelet aggregates after reperfusion exacerbates vessel lumen obliteration, coronary microvascular constriction, oxidative stress injury, and release of proteolytic enzymes and pro-inflammatory mediators which drive further MVO [1-3,16]. Pericytes that cover the coronary capillaries also contract during post-ischaemia reperfusion, contributing to the reduction in microvascular blood flow. Myocardial interstitial oedema is also enhanced in early reperfusion by the washout of osmotically active mediators from the intravascular space during reactive hyperaemia. The most severe manifestation of coronary microcirculatory injury due to reperfusion is intramyocardial haemorrhage (IMH) - after substantial endothelial disruption, erythrocyte extravasation into the perivascular space, and inflammatory and coagulation cascade activation resulting in thrombosis and coagulation factor consumption. IMH-induced interstitial iron deposition is visible on cardiac magnetic resonance imaging (CMR) T2-weighted and T2*-weighted sequences in $40 \%-80 \%$ of patients with MVO [5,21], and can induce an inflammatory response to further intensify MVO. Importantly, patients with IMH and MVO have a worse outcome than those with MVO without IMH [5].

\subsection{Distal Microembolisation}

Distal coronary microembolisation is the final key mechanism underpinning myocardial injury and MVO. The spontaneous or iatrogenic (PCI-induced) rupture of atherosclerotic epicardial plaque releases particulate debris which, together with superimposed microthrombi, embolises distally into the coronary microcirculation. This microvascular plugging by inflamed plaque fragments contributes to MVO (represented as the coronary no-reflow phenomenon), and subsequent peri-procedural MI. In STEMI, distal embolization of thrombotic microemboli and atherothrombotic debris has been increasingly recognised 
as an important mechanism contributing to coronary microcirculatory impairment. In an extensive microscopic examination of 25 cases of sudden death due to acute coronary thrombosis, Falk provided conclusive support for spontaneous, mainly thrombotic, distal embolization leading to occlusion of small intramyocardial arteries and microinfarctions [22]. Furthermore, microvascular fibrin and platelet aggregates are found in patients dying of MI [23].

Coronary no-reflow describes the inability to reperfuse regions of previously ischaemic myocardium after the restoration of flow in the occluded coronary artery, and angiographically can be visualised as impaired penetration of contrast distally into the myocardium [11,16]. It is important to note however that distal embolization, whether by iatrogenic rupture of an atherosclerotic plaque via angioplasty or spontaneous plaque erosion during the ACS, releases both particulate debris as well as soluble factors which impair microvascular perfusion but cannot be captured with filter devices or meshes [3,24]. This process is believed to be mediated in part by activated neutrophils in vulnerable coronary plaque, and enhanced release of neutrophil-derived mediators such as neutrophil extracellular traps (NETs) and microparticles which promote pro-thrombotic and proinflammatory cascades via neutrophil-platelet aggregate formation, complement cascade activation, inflammatory cytokine release from activated endothelial cells, ROS generation causing oxidative damage, and local tissue degradation [25-28]. This cascade is further augmented by angioplasty-induced plaque rupture and exposure of tissue factors which promotes thrombosis and subsequent MVO [29]. In STEMI patients post-primary PCI, coronary NETs burden correlates positively with infarct size and negatively with ST-elevation resolution [28].

\subsection{Inflammation}

Inflammatory activation is triggered by myocardial ischaemia and necrosis; mediating tissue healing, scar formation and ventricular remodelling, and serving as a potent contributor to cardiac MVO [30,31]. After the acute phase of a myocardial infarction, a robust systemic inflammatory response is driven primarily by the infiltration and activation of neutrophils, followed by monocyte/macrophages and lymphocytes. This response, aiming to remove cellular debris and repair injured tissue, is mediated by the release of various cytokines and acute-phase proteins [31,32]. In particular, cellular debris activates the NLRP3 inflammasome - a macromolecular protein complex that regulates caspase 1 activation and subsequent production of potent pro-inflammatory cytokines IL-1ß and IL-18 [31,33]. The inflammasome potentiates the inflammatory response in ACS by amplifying tissue injury and leading to interstitial myocardial oedema, which compresses capillaries and arterioles in the coronary microcirculation, causes arteriolar spasm and other progressive endothelial abnormalities, and results in erythrocyte stasis and micothrombosis within the microvasculature, all of which contribute to MVO [34,35]. Produced downstream of the inflammasome, IL-6 induces C-reactive protein (CRP) synthesis and acts as a secondary mediator of the inflammatory cascade [33]. There is growing evidence to suggest that CRP is not only a marker of atheroinflammation and cardiovascular risk, but is also a mechanistic proinflammatory mediator of myocardial damage and MVO. Experimental studies [32,34,35] have demonstrated that CRP promotes myocyte apoptosis, increases infarct size, and impairs infarct healing in a rat model; and overexpression exacerbates ventricular remodelling after myocardial infarction. In a multitude of human clinical studies [32,35-40], elevated CRP levels post-myocardial infarction have been shown to be associated with larger infarct size, development of heart failure, adverse LV remodelling, and MVO as evaluated by CMR. CRP induces myocardial and endothelial injury via direct and indirect stimulation of the coagulation and complement cascade, particularly by altering the fibrinolytic balance of endothelial cells and promoting intravascular fibrin formation, and it is postulated that this process contributes to MVO in ACS patients [34,40]. 


\section{Diagnosis of MVO during Evolving ACS}

The diagnosis of MVO is made using both non-invasive and invasive tools, with incidence rates ranging from $10 \%$ angiographically to $60 \%$ using CMR $[1,2]$. The discrepancy in MVO diagnosis between various modalities can be attributed to the fundamental differences in assessing functional alterations in coronary blood flow and structural changes at a tissue level. Furthermore, MVO is a dynamic process with the potential for reversible and irreversible damage (approximately 50\% in each cohort) [41]. Therefore, the timing of evaluation (early after reperfusion vs. late via CMR) is a key factor in determining microcirculatory dysfunction [11] in an evolving ACS setting. Importantly, most studies of MVO have been limited to STEMI patients with the few studies in non-ST elevation myocardial infarction (NSTEMI) patients limited by small patient sizes. A larger study of 190 NSTEMI patients [42] reported an MVO incidence rate of $13.8 \%$ using CMR and established culprit lesion and infarct size as independent predictors of MVO.

\subsection{Invasive Indices}

a Angiography

Thrombolysis in myocardial infarction (TIMI) flow is a widely recognised angiographic visual scoring system from 0 to 3 grading epicardial coronary flow, ranging from no flow to complete antegrade flow to the distal vessel which is associated with less MVO, smaller infarct size, fewer MACE, and better survival $[1,16]$. Although fast and easy to use, over half of all patients with TIMI 3 flow demonstrate ongoing CMR-determined MVO, thereby limiting its sensitivity and predictive power [43]. A variation on this approach is the corrected TIMI frame count (cTFC) which provides a quantitative index to evaluate coronary flow by counting the number of frames required for contrast medium to reach a standardised landmark, although its reproducibility outside of core labs and prognostic value is not clear [1,16]. Myocardial blush grade (MBG) and TIMI MBG are two other methods developed to evaluate the kinetics of dye penetration into the myocardium, shifting attention away from epicardial coronary flow to the microcirculation. MBG is a densitometric method evaluating myocardial contrast blush (and hence perfusion) after injection, ranging again from 0 to $3[3,16]$. It provides additional diagnostic value to TIMI flow as in patients with TIMI 3 flow, two-thirds demonstrated MBG grade 0 to 1 ; and it has important prognostic value independent of TIMI flow [44]. However, once again, preserved MBG does not necessarily confirm sufficient microvascular perfusion, and a large subset of patients with MBG grade 2-3 show CMR-determined MVO [43,45].

b Coronary physiology

Invasive assessments of coronary epicardial and microvascular function can be performed with an intracoronary sensor-tipped guidewire [46]. Coronary physiologic indices proposed for assessment of the coronary microcirculatory function include coronary flow reserve (CFR), index of microcirculatory resistance (IMR), hyperaemic microvascular resistance (HMV), and resistive reserve ratio (RRR) [16]. CFR interrogates the epicardial and microvascular coronary circulation and can be derived using Doppler or thermodilution techniques, as either the ratio of hyperaemic blood flow divided by resting flow or mean transit time (Tmn) at rest divided by Tmn during hyperaemia. A CFR value $<2.0$ has a sensitivity of $79 \%$ and specificity of $34 \%$ for CMR-determined MVO, and CFR of the infarct-related artery portends prognostic value such as LV function post-MI and long term mortality $[16,47]$. However, CFR is limited by poor reproducibility and variations in measurement depending on systemic haemodynamic conditions such as heart rate, blood pressure, and left ventricular contractility [48]. IMR, on the other hand, is a more specific and reproducible measure of the microcirculation independent of haemodynamic parameters or the severity of epicardial stenoses [49,50]. IMR, measured using a pressuretemperature sensor guidewire under peak hyperaemia (induced via adenosine infusion), after three intracoronary injections of room temperature saline, is equal to the hyperaemia distal arterial pressure $\left(P_{d}\right)$ multiplied by the hyperaemic Tmn (IMR $=P_{d} \times$ Tmn). IMR 
is an appealing diagnostic technique as it can be measured immediately during primary $\mathrm{PCI}$ and thereby identify high-risk patients requiring more intensive follow-up or early intervention with novel therapies targeting MVO and aimed at microvascular recovery. A meta-analysis found that IMR is significantly higher in patients with CMR-determined MVO [51]. In STEMI patients, IMR was an independent predictor of myocardial salvage ( $13 \%$ decrease in salvage for every $20 \%$ rise in IMR) and LV ejection fraction $(p<0.01)$. IMR has also been shown to predict infarct size, 3-month echocardiographic wall motion score, and peak creatinine kinase and troponin levels better than TIMI grade or CFR $[50,52,53]$. In a landmark study of 253 STEMI patients, IMR $>40$ (which occurred in $32 \%$ of patients) was a powerful independent predictor of the primary endpoint (death and heart failure hospitalisation) at one year $(17.1 \%$ vs. $6.6 \%, p=0.027)$ and at three years $(20 \%$ vs. $11 \%$, $p=0.04$ ) compared to those with IMR $\leq 40$ [8]. HMV is calculated as distal pressure divided by the mean Doppler flow velocity at peak hyperaemia using a coronary guidewire with a pressure sensor and Doppler transducer, with a value $>2.5 \mathrm{mmHg} \mathrm{cm}^{-1}$ s indicative of CMR-determined MVO (sensitivity 71\%, specificity 63\%) [16]. Although there is some data associating higher HMV with poor ventricular recovery and higher MACE (death and heart failure rehospitalization) [54,55], its role in evolving ACS has been studied less than IMR and a major limitation is the difficulty in acquiring high-quality measurements using the Doppler wire. Finally, the RRR measures the ability to achieve maximal coronary hyperaemia and quantifies the vasodilator response of the coronary microcirculation as the ratio of basal resistance (without adenosine) to IMR at peak hyperaemia, with lower values seen in STEMI patients [16].

\section{c Intracoronary ECG}

Intracoronary ECG has also been proposed as an early, simple and objective method of diagnosing MVO and predicting infarct zone recovery "real-time" during primary PCI, thereby identifying patients suitable for potential therapeutic interventions or careful follow-up [56]. In a study of 64 STEMI patients undergoing primary PCI [57], intracoronary ST-segment resolution ( $\geq 1 \mathrm{~mm}$ improvement compared to baseline) correlated with MVO $(p=0.005)$ on contrast-enhanced CMR assessed day 4 post-STEMI; as well as infarct size, non-viable mass, peak creatinine-kinase and left ventricular remodelling at 3 months post-STEMI.

\subsection{Non-Invasive Indices}

After primary PCI, incomplete ST-elevation resolution has been related to MVO and portends a worse clinical outcome [58], although this modality lacks specificity or quantitative ability, and is quite dynamic during an evolving ACS. Myocardial contrast echocardiography utilizes ultrasound to visualise contrast microbubbles with a rheology akin to red blood cells, and lack of intra-myocardial contrast opacification due to MVO is predictive of left ventricular remodelling post-STEMI [1]. However, again, this modality is limited by spatial resolution, operator dependence, semi-quantitative assessment, and incomplete LV coverage with suboptimal visualisation.

Myocardial perfusion positron emission tomography (PET), based on radiotracers labelled with isotope-emitting positrons, represents a well-validated imaging modality for the identification of CMD with high diagnostic accuracy, temporal resolution, and sensitivity. Rest and stress PET allows for quantification of indices of microvascular dysfunction such as absolute myocardial blood flow (MBF), myocardial perfusion reserve (MBF at maximal stress), and coronary flow reserve (ratio of MBF during maximal coronary vasodilatation to resting MBF) $[59,60]$. Hybrid positron emission tomography-computed tomography (PET-CT) has also been utilised for MVO evaluation, by measuring regional 18F-deoxyglucose (FDG) uptake, with promising results as it allows for quantification of myocardial tissue inflammation after reperfusion [61].

Finally, CMR is the gold standard non-invasive diagnostic modality for MVO, allowing multislice imaging with high tissue contrast and spatial resolution, enabling quantification and localization of MVO and infarct size, as well as regional contractile function. On 
contrast-enhanced CMR, MVO is identified as a dark hypointense core (lack of gadolinium enhancement) during first pass ( $<2 \mathrm{~min}$ ) or after conventional late (10-15 min) gadolinium enhancement of the affected myocardium. First pass (early) MVO is more sensitive than late MVO to subtle microvascular injury, as the latter often underestimates severity. However, the prognostic utility of early MVO for the prediction of postinfarction MACE is lower, as late MVO represents severely disturbed microcirculation and hence correlates more strongly with worse outcomes $[1,2,43,62,63]$. Newer techniques in CMR further facilitate infarct characterization, identification of $\mathrm{IMH}$, and quantification of oedema and myocyte loss [16]. A key point of variability between CMR evaluation of MVO is the timing of image acquisition due to the dynamic course of microvascular injury, and this has led to standardised protocols for postinfarction CMR imaging to ensure the validity of the acquired data [2].

\section{Therapeutic Approaches in MVO}

Over the course of several years, many therapies have been trailed to prevent as well as treat $\mathrm{MVO}$, and this represents an ongoing unmet need in interventional cardiology. However, unfortunately, there still exists no treatment which has convincingly demonstrated benefit in an adequately powered randomised control trial with clinical endpoints. Regardless, we will summarise various treatments which have been investigated as well as possible future directions in the field.

\subsection{Beta Blockers}

Pre-clinical data has shown that third-generation beta-blockers (carvedilol, nebivolol) may reduce infarct size and protect the coronary microcirculation [2]. Intravenous administration of metoprolol before reperfusion in an animal model has been shown to reduce infarct size and MVO, by modulating the inflammatory response inhibiting neutrophilplatelet aggregates [64]. In a study (METOCARD-CNIC) of 270 patients with anterior STEMI, ambulance intravenous metoprolol $(3 \times 5 \mathrm{mg})$ administered pre-PCI reduced infarct size, prevent LV adverse remodelling, preserved LV systolic function, and reduced future heart failure readmissions [65]. A subanalysis of this trial [66] demonstrated that in control patients, there was a positive correlation between neutrophil count and extent of $\mathrm{MVO}$, whereas in the treatment arm this was not the case, suggesting that administration of metoprolol during ongoing ACS does not affect circulating neutrophil levels but in fact modulates the effect of neutrophils on MVO. However, another study [67] (EARLY BAMI) of 683 patients failed to demonstrate any reduction in infarct size (CMR-determined) in STEMI patients given intravenous metoprolol $(2 \times 5 \mathrm{mg})$ just before primary PCI.

\subsection{Statins}

Several studies have proposed that acute statin treatment may mitigate MVO via pleiotropic effects such as improvement in endothelial function, coronary microvascular dilatation, and anti-inflammatory and anti-thrombotic mechanisms. However, the evidence regarding this remains conflicting. Chronic ongoing statin therapy at the time of STEMI is associated with a lower rate of coronary no-reflow, and more favourable LV ejection fraction and ventricular remodelling [68]. In 171 STEMI patients (STATIN STEMI) [69], high-dose atorvastatin pre-treatment did not reduce MACE but did improve coronary flow after primary PCI, as assessed angiographically by cTFC and MBG. In the SECURE-PCI trial, 4191 patients with ACS were randomised to receive two loading doses of $80 \mathrm{mg}$ atorvastatin or placebo before and $24 \mathrm{~h}$ after planned PCI, followed by $40 \mathrm{mg}$ daily thereafter. At 30 days, however, rates of MACE were not lower in the treatment arm, although in the subgroup of 1012 STEMI patients the difference was statistically significant in favour of the treatment cohort $(8.5 \%$ vs. $12.6 \%$, hazard ratio [HR] 0.66). Finally, a smaller study [70] of STEMI patients given $80 \mathrm{mg}$ atorvastatin pre-PCI and for 5 thereafter versus controls (10 mg daily post-PCI) did not improve infarct size measured by technetium Tc $99 \mathrm{~m}$ single-photon emission computed tomography, MBG, or ST-segment elevation resolution. 


\subsection{Adenosine}

Adenosine is a potent direct vasodilator of the coronary microcirculation and also has a range of purported pleiotropic effects including anti-inflammatory properties against neutrophils, inhibition of platelet aggregation, antiapoptotic effects, and stimulation of angiogenesis [71]. However, clinical studies have displayed mixed results in attenuation of MVO and infarct size. In the AMISTAD-II study [72,73] of over 2000 anterior STEMI patients receiving thrombolysis or primary PCI, patients were randomised to a 3-h adenosine infusion or placebo. Here, clinical outcomes were not improved overall in the adenosine arm but infarct size as assessed by technetium- $99 \mathrm{~m}$ sestamibi tomography was reduced in patients who received $70 \mathrm{mcg} / \mathrm{kg} / \mathrm{min}$ adenosine dosing. Furthermore, in a post hoc analysis, adenosine administered within the first $3.2 \mathrm{~h}$ of evolving anterior STEMI (from chest pain onset) enhanced 1-month and 6-month survival compared to placebo, and the composite endpoint of death or heart failure at 6 months. In the REOPEN-AMI trial $[74,75]$ of 240 STEMI patients treated with primary PCI and thrombus aspiration, the additional intracoronary administration of adenosine (but not nitroprusside) resulted in a significant improvement in MVO as assessed by ST-elevation resolution ( $51 \%$ vs. $71 \%, p=0.009$ ) but not TIMI flow grade and MBG ( $18 \%$ vs. $30 \%, p=0.06)$ or MACE at 30 days $(10 \%$ vs. $20 \%$, $p=0.08)$ compared to placebo. At one-year follow-up, however, the adenosine cohort had reduced MACE and better LV remodelling compared to placebo or the nitroprusside arm. In contrast, however, the REFLO-STEMI trial [76] of 247 STEMI patients failed to confirm these findings, and in fact, demonstrated a similar extent of MVO but larger infarct size, lower LV ejection fraction, and higher rates of MACE at 30 days and 6 months in the high dose intracoronary adenosine cohort compared to placebo.

\subsection{Atrial Natriuretic Peptide}

Atrial natriuretic peptide (ANP) suppresses endothelin-1 production and acts on the reperfusion injury salvage kinase (RISK) cardioprotective pathway which is involved in ischaemic preconditioning, thereby exerting possible favourable effects on MVO [77]. In the J-WIND trial, carperitide (ANP agonist) treatment resulted in a reduction in enzymatic infarct size and improved LV ejection fraction in STEMI patients treated pre-PCI compared to placebo. However, there remains a paucity of clinical study data evaluating the effect of ANP on MVO.

\subsection{Exenatide}

Exenatide, a glucagon-like peptide- 1 agonist, has been proposed to reduce infarct size and preserve cardiac function in pre-clinical models, by reducing myocardial apoptosis and oxidative stress. Unfortunately, human trials have been limited by conflicting results. In an initial study of 172 STEMI patients [78], the exenatide-treated patients demonstrated larger myocardial salvage index and smaller infarct size $(p=0.003)$ on CMR compared to controls, and this was further reinforced in a smaller study of 58 patients where the absolute mass of delayed hyperenhancement (suggestive of MVO on CMR) in exenatide-treated patients was significantly reduced compared to controls $(p<0.01)$ [79]. However, a subsequent larger study of 191 patients showed no difference between the two groups (exenatide infusion vs. placebo) in terms of infarct size on CMR corrected for the area at risk $(p=0.662)$ [80].

\subsection{Antiplatelet Therapy}

Current practise guidelines [81] recommend (Class IIA, evidence level C) GP IIb/IIIa inhibitor therapy (abciximab, tirofiban, or eptifibatide) in patients with slow or no-reflow, given either intravenously or intracoronary initially as a bolus followed by a maintenance infusion, although the evidence remains conflicting. In the FINESSE trial [82] of 2452 STEMI patients, upstream abciximab administration with half-dose reteplase significantly reduced infarct size but not MACE or mortality at 90 days or one year. In 110 patients with acute myocardial infarction, however, early abciximab administration did not lead to smaller CMR-determined infarct size at 6 months overall except in patients with a longer 
transportation time [83]. In the RELAX-AMI trial [84] of 210 STEMI patients treated with primary $\mathrm{PCI}$, early abciximab therapy improved pre-PCI angiographic findings (TIMI flow grade, CTFC, MBG), post-PCI tissue perfusion (ST-elevation resolution and MBG), and one-month LV function recovery $(p=0.03)$ compared to later therapy in the catheterisation lab. The ON-TIME 2 trial [85] of 984 STEMI patients demonstrated that routine pre-hospital initiation of high-dose tirofiban improved ST-elevation resolution and clinical outcomes post-PCI. In the INFUSE-AMI study [86] of 452 anterior STEMI patients, infarct size and mass $(p=0.03)$ measured with CMR at 30 days was reduced by bolus intracoronary abciximab delivered to the infarct lesion site compared to placebo. Finally, in AIDA STEMI [87], the only trial powered for clinical outcomes with 2065 STEMI patients, there was no difference between intracoronary and intravenous administration of abciximab in terms of MACE and MVO rate (CMR-assessed) at follow-up.

Experimental data has also examined the role of P2Y12 inhibitors in reducing MVO and infarct size when administered at the onset of reperfusion or earlier. In a small study of 84 STEMI patients who received upstream clopidogrel treatment prior to $\mathrm{PCI}$, there was a significantly lower rate of MVO on CMR (odds ratio [OR] 0.39, $p=0.002$ ) [88]. However, a subanalysis of the PLATO trial comparing ticagrelor and clopidogrel did not find any difference in myocardial perfusion or coronary flow as assessed by TIMI flow grade or MBG [89]. In the ATLANTIC study of 1862 STEMI patients [90], pre-hospital administration of ticagrelor did not improve pre-PCI coronary reperfusion. The REDUCE-MVI trial [91] of 110 STEMI patients found no difference between ticagrelor and prasugrel in reducing MVO or infarct size, as assessed by invasive IMR evaluation and CMR at one month. The ongoing PITRI trial will aim to determine whether intravenous cangrelor administered prior to reperfusion reduces infarct size or MVO as assessed by CMR [92].

\subsection{Ischaemic Conditioning}

Ischaemic conditioning, defined by either repeated brief episodes of mechanical ischaemia/reperfusion before PCI or at the onset of reperfusion, has been proposed as a cardioprotective therapy in several clinical studies, by increasing myocyte resistance to ischaemic injury. Post-conditioning refers to interrupted reperfusion with alternating brief coronary artery re-occlusion-reperfusion cycles. In a study of 118 STEMI patients, patients in the treatment arm demonstrated better ST-elevation resolution and smaller CMR-determined infarct size, but no difference in clinical outcomes at 15 months [93]. In a trial of 122 STEMI patients [94], post-conditioning did not improve infarct size, myocardial salvage, or LV ejection fraction two days post-PCI, but at 12 months, CMR demonstrated more favourable remodelling $(p<0.03)$ and less MVO $(p=0.05)$ in the therapy cohort. In the much larger POST trial of 700 STEMI patients, however, 4 cycles of 60-s angioplasty balloon inflation-deflation did not improve myocardial reperfusion (MBG), ST-elevation resolution, or MACE at 30 days [95]. Finally, the large multicentre DANAMI-3-iPOST trial of 1234 STEMI patients [96], involving four repeated 30-s cycles before stent implantation, found no difference in MACE (HR 0.93, $p=0.66$ ), or CMR-evaluated infarct size, myocardial salvage index, the extent of MVO, or LV ejection fraction at 3 months.

On the other hand, remote ischaemic post-conditioning (RIPC), using several cycles of brief limb ischaemia and reperfusion, has shown some promise in smaller studies but not larger trials powered for hard outcomes. In the CONDI trial of 333 STEMI patients, four cycles of 5-min arm (blood pressure cuff) ischaemia alternating with reperfusion during ambulance transport pre-PCI improved myocardial salvage $(p=0.03)$ and hence infarct size as assessed by myocardial perfusion imaging [97]. This was further reinforced in a smaller study of 100 anterior STEMI patients, where 3-cycle lower limb RIPC at the time of primary PCI reduced enzymatic infarct size, tissue oedema volume (on CMR), and improved ST-elevation resolution [98]. Similarly, a study of 197 STEMI patients receiving 4-cycle upper arm RIPC prior to primary PCI demonstrated reduced CMR-assessed infarct size, enhanced myocardial salvage, and less tissue oedema in the treatment cohort [99]. In the LIPSIA CONDITIONING trial of 696 STEMI patients, post-conditioning alone with 
four 30-s re-occlusion/reperfusion cycles did not improve myocardial salvage or MVO as assessed by CMR, but when combined with RIPC (three 5-min upper arm cycles) it improved myocardial salvage [100], translating into reduced MACE (OR 0.56, $p=0.04$ ) and heart failure (OR 0.32, $p=0.02$ ) at over three years follow-up [101]. Finally, however, the very large CONDI-2/ERIC-PPCI trial of 5401 STEMI patients [102], which compared standard care including sham simulated RIPC to four 5-min upper arm RIPC cycles before PCI, found no difference in MACE (HR 1.1, $p=0.32$ ), i.e., cardiac death or heart failure hospitalisation, at 12 months.

\subsection{Interventional Procedures}

a Aspiration thrombectomy

Initial smaller studies evaluating manual thrombus aspiration, purported to improve myocardial perfusion and attenuate MVO by reducing distal embolisation of atherothrombotic debris, showed promising results but this did not translate into a benefit in larger trials. In the small REMEDIA trial of 100 STEMI patients, manual aspiration improved MBG (OR 2.6, $p=0.02$ ) and ST-elevation resolution (OR 2.4, $p=0.034$ ) [103]. Similarly, the TAPAS study of 1071 patients demonstrated better MBG (relative risk [RR] 0.65, $p<0.001$ ) and ST-elevation resolution (RR 1.28, $p<0.001$ ) [104] in the treatment cohort. At one year follow-up, this translated into less cardiac mortality and non-fatal reinfarction (HR 1.81, $p=0.009$ ) for patients receiving aspiration thrombectomy [105]. In a meta-analysis of nine trials with 2417 patients, adjunctive aspiration thrombectomy was associated with better epicardial TIMI flow grade perfusion $(p<0.0001)$, post-procedural MBG $(p<0.0001)$, less distal embolisation $(p<0.0001)$, and significant 30 -day mortality benefit $(1.7 \%$ vs. $3.4 \%$, $p=0.04)$ [106].

However, in the much larger TASTE trial of 7244 STEMI patients, there was no difference at 30 days between the aspiration thrombectomy arm and controls in all-cause mortality (HR 0.94, $p=0.63$ ), hospitalisation for recurrent myocardial infarction (HR 0.61, $p=0.09$ ), or stent thrombosis (HR 0.47, $p=0.06$ ) [107]. These findings were reaffirmed at one year follow-up as well for all-cause mortality (HR 0.94, $p=0.57$ ), recurrent myocardial infarction hospitalisation (HR 0.97, $p=0.81$ ), and stent thrombosis (HR 0.84, $p=0.51$ ) [108]. Similarly, in the TOTAL trial of 10732 STEMI patients, there was no difference in the primary outcome (cardiovascular death, recurrent myocardial infarction, cardiogenic shock, or New York Heart Association [NYHA] Class IV heart failure; HR 0.99, $p=0.86$ ) but stroke within 30 days was higher in the thrombectomy arm compared to controls (HR 2.06, $p=0.02$ ) [109]. On the other hand, in patients with angiographic evidence of a large thrombus burden, the use of the Angiojet mechanical thrombectomy device in the JETSTENT study of 501 STEMI patients was associated with improved ST-elevation resolution $(p=0.043)$ and reduced $\operatorname{MACE}(p=0.011)$ at 6 months [110]. In the MASTER trial of 433 STEMI patients, patients were randomised to either conventional stent implantation or a novel polyethylene terephthalate micronet mesh-covered stent, designed to trap and exclude thrombus and friable atheromatous debris, to prevent distal embolisation [111]. Here, the MGuard stent improved ST-elevation resolution $(p=0.008)$ and TIMI flow grade $(p=0.006)$ but not MBG $(p=0.81)$, mortality $(p=0.06)$ or MACE $(p=0.75)$ at 30 days.

b Deferred coronary stenting in STEMI

Importantly, there has also been an examination of whether deferred stenting (after successful reperfusion with initial thrombectomy and/or balloon angioplasty) might reduce no-reflow and salvage myocardium in high-risk STEMI patients, particularly in the DEFERSTEMI pilot trial [112]. Comparing immediate stenting to deferred (intention-to-treat) stenting 4-16 h later in selected patients at risk of no-reflow, fewer patients in the deferred cohort had no-/slow-reflow based on TIMI flow grade (OR 0.16, $p=0.006)$ and intraprocedural thrombotic events $(p=0.01)$. Of the 52 patients randomised to deferred stenting, recurrent STEMI occurred in 2 patients before the planned second procedure. Myocardial 
salvage index at 6 months was also lower in the deferred cohort compared to controls $(p=0.031)$, but there was no difference in CMR-assessed MVO at two days $(p=0.155)$.

c Intermittent Coronary Sinus Occlusion

Pressure-controlled intermittent coronary sinus occlusion (PICSO) has been proposed as a means of improving microvascular perfusion and reducing MVO, by redistributing venous blood to the border zone of ischaemic myocardium, thereby enhancing washout of injurious agents in the microcirculation and inducing the release of vascular endothelial growth factors [2]. In the OxAMI-PICSO observational study of 105 STEMI patients, selected patients treated with PICSO (if pre-PCI IMR $>40$ ) had a lower IMR at $24-48$ h $(24.8$ vs. $45, p<0.001)$ and lower infarct size on CMR at 6 months $(26 \%$ vs. $33 \%$, $p=0.006)$ [113]. There is however no randomised data supporting its routine use.

\subsection{Intracoronary Thrombolysis}

There is a growing body of evidence supporting the hypothesis that intracoronary thrombolysis improves microvascular perfusion in STEMI patients, by induction of fibrinolysis and inhibition of red cell and platelet aggregation contributing to MVO. In a landmark study, 41 STEMI patients were randomized to low-dose intracoronary streptokinase (STK) $(250 \mathrm{kU})$ immediately post-PCI or no additional therapy [114]. Intracoronary STK was associated with improved measures of microvascular perfusion, including IMR (11.7 in STK arm vs. 29.1 in controls, $p<0.001)$, CFR (2.3 vs. $1.7, p=0.002)$ and TIMI frame count (19.1 vs. $27.5, p=0.001$ ). In a subsequent larger study of 95 patients by the same authors [115], patients receiving low-dose intracoronary STK had better two-day invasive microvascular function indices including CFR (2.5 vs. 1.7, $p<0.001)$ and IMR (20.2 vs. $34.2, p<0.001)$ that correlated with reduction in infarct size $(22.7 \%$ vs. $32.9 \%, p=0.003)$ and improvement in left ventricular ejection fraction $(57.2 \%$ vs. $51.8 \%, p=0.018)$ at 6 months. However, another recent study of 76 anterior STEMI patients compared the effects of intracoronary tenecteplase to abciximab during primary $\mathrm{PCI}$, and found better angiographic parameters including CTFC (14.1 vs. $18.2, p=0.02)$ and TIMI flow grade $(p=0.03)$ in the abciximab cohort two days later, as well as no difference in infarct size on CMR at four months follow-up $(p=0.33)[116,117]$. Furthermore, the T-TIME study of 440 randomised patients, evaluating low-dose intracoronary alteplase (10 or $20 \mathrm{mg}$ ) infused early after coronary reperfusion and before stenting to attenuate MVO in the STEMI population [118], was stopped early due to futility as there was no difference in CMR-assessed MVO (\%left ventricular mass) between alteplase $20-\mathrm{mg}$ and placebo (3.5\% vs. $2.3 \%, p=0.32$ ) or $10-\mathrm{mg}$ and placebo $(2.6 \%$ vs. $2.3 \%, p=0.74)$. Interestingly, higher prothrombin concentrations in the alteplase group suggested that the undesired procoagulant effect of fibrinolytic therapy via thrombin activation may have contributed to microvascular thrombosis, especially in patients with inadequate therapeutic anticoagulation with unfractionated heparin.

Two ongoing trials will stratify enrolment and patient selection based on IMR after primary PCI, hoping to identify the specific STEMI patient population most at risk of clinically significant MVO and therefore most likely to derive benefit from putative therapies. These two trials are the OPTIMAL study (www.clinicaltrials.gov; Unique Identifier NCT02894138) of 80 patients (IMR > 30 randomised to $20 \mathrm{mg}$ alteplase or placebo) and the RESTORE-MI trial (Australia New Zealand Clinical Trials Registry; Number 12618000778280) of up to 800 patients (IMR > 32 randomised to low-dose tenecteplase or placebo). In RESTORE-MI, a large phase 3 double-blinded placebo-controlled multicentre randomised trial, initially 243 patients will be recruited in a 1:1:1 fashion (one-third systemic tenecteplase dose, onesixth systemic tenecteplase dose, and placebo) as part of a dose-finding and cardiac MRI study to evaluate infarct size at 6 months. Subsequently, after determining the optimal tenecteplase dose with a significant infarct size reduction but no substantial predisposition to adverse events such as bleeding, a larger study of 800 randomised patients (with IMR > 32 post-PCI) will aim to determine whether low-dose tenecteplase improves cardiovascular mortality and heart failure rehospitalisation at 24 months compared to placebo. 


\subsection{Novel and/or Future Therapies}

A plethora of less well-known prospective and experimental therapies have also emerged recently as potential targets of coronary MVO but remain to be comprehensively evaluated in large clinical trials.

It is well established that NETs are induced during ischaemia-reperfusion and distal microembolisation post-PCI and correlate with infarct size [26,28], and that NET-mediated microthrombosis contributes to myocardial "no-reflow" and MVO. Compared to controls in a rat model, a combination of DNase1 and recombinant tissue-type plasminogen activator $($ rt-PA) reduced NET density $(p<0.001)$ and "no-flow" area $(p<0.05)$ in the ischaemic region, reduced infarct size $(p<0.001)$ after $3 \mathrm{~h}$ of reperfusion, and ameliorated LV remodelling $(p<0.05)$ [119]. Further studies of this therapy in humans are required to determine whether this approach can attenuate MVO.

ITF-1697 is a C-reactive protein-derived tetrapeptide which, based on pre-clinical studies, was proposed to reduce reperfusion injury to hence MVO. However, in a randomised dose-finding study of 402 patients undergoing primary PCI, there was no difference in TIMI flow, cTFC, MBG, ST-elevation resolution, enzymatic infarct size, or clinical outcome between the placebo or treated patients [120]. Enhanced mitochondrial permeability and subsequent mitochondrial swelling drives reperfusion injury and cell death, and attenuation of this has been another proposed target in ACS patients. However, trials of intravenous TR040303 (an inhibitor of mitochondrial permeability transition pores) and Bendavia (a mitochondria-targeted peptide) failed to demonstrate benefit in STEMI patients [1]. Similarly, agents targeting microthrombosis such as pexelizumab [121] (a humanised monoclonal antibody inhibiting C5 complement) and FX06 [122] (a peptide derived from human fibrin) have also failed to improved outcomes, infarct size, or MVO as assessed by CMR.

A multitude of anti-inflammatory therapies have also been evaluated in patients with ACS, but despite early encouraging results in pre-clinical models, to date, none have convincingly demonstrated attenuation of MVO [30]. IL-1 inhibition, with concomitant downstream IL-6 and CRP suppression, has been investigated most extensively in this domain of the literature and is an emerging target in heart failure management. In the CANTOS trial [123] of 10061 prior myocardial infarction patients with a high-sensitivity CRP level $\geq 2 \mathrm{mg} / \mathrm{L}$, canakinumab (a monoclonal antibody targeting IL-1ß) therapy reduced recurrent cardiovascular events (HR $0.85, p=0.021$ ) over median 3.7 years follow-up, and there was a dose-dependent reduction in heart failure hospitalisation and heart failurerelated mortality $(p=0.037)$ [124], although MVO specifically was not evaluated. A variety of experimental and smaller clinical trials of colchicine (an anti-mitotic drug which inhibits NLRP3 inflammasome activation) and anakinra (recombinant IL-1 receptor antagonist) in ACS patients have also demonstrated favourable heart failure-related endpoints such as infarct size, the incidence of adverse remodelling, quality of life scores, rehospitalisation rates, and peak aerobic exercise capacity [31,125]. In particular, in the VCUART3 trial of 99 STEMI patients $[125,126]$, anakinra significantly reduced the systemic inflammatory response compared to placebo, and this translated into a reduced incidence of death and new-onset heart failure $(p=0.046)$ or heart failure hospitalisation $(p=0.011)$, although again there was no data with respect to MVO.

The CHILL-MI study of 120 STEMI patients aimed to evaluate the cardioprotective effects of hypothermia using a combination of cold saline rapid infusion and endovascular cooling starting pre-PCI and up to $1 \mathrm{~h}$ after reperfusion [127]. Here, there was no difference between the treatment arm and controls in CMR-assessed infarct size as a percent of myocardium at risk $(p=0.15)$, but there was a lower incidence of heart failure ( $3 \%$ vs. $14 \%$, $p<0.05)$ and a possible favourable effect in early anterior STEMI patients $(p<0.05)$ on subgroup analysis, but these need further confirmation in larger trials.

Emerging data suggest that severe MVO and IMH post-PCI, with residual myocardial iron deposition, can lead to ongoing inflammation and adverse LV remodelling. Experimental studies suggest deferoxamine iron chelation may limit ROS generation, and hence 
reduce ischaemia-reperfusion injury and subsequent infarct size. In a small study of 60 STEMI patients, however, there was a significant reduction in plasma $\mathrm{F}(2)$-isoprostane levels post-PCI in the treated cohort $(p=0.04)$, indicating amelioration of oxidative stress, but no difference in CMR-determined infarct size $(p=0.73)$ versus placebo [128]. Importantly, this study enrolled all unselected STEMI patients and therefore it is possible that future studies selecting only patients with evidence of IMH on CMR may provide a more favourable result.

Finally, temanogrel is an investigational selective 5-HT2A receptor inverse agonist designed to inhibit serotonin-mediated amplification of platelet aggregation and vasoconstriction. The upcoming ARENA study (www.clinicaltrials.gov accessed 14 July 2021; Unique Identifier NCT04848220) in patients undergoing PCI will aim to determine whether temanogrel is a safe and effective treatment of $\mathrm{MVO}$, with the primary outcome being a change in IMR.

\section{Conclusions}

The crucial role of the microcirculation in determining short-term and long-term prognostic clinical outcomes after an ACS is manifest in the literature and continues to emerge as an untapped frontier for potential future therapies. Unfortunately, efforts to date aimed at improving outcomes in patients with MVO have been met with limited success, most likely because it is a multifactorial process with several interdependent underlying pathophysiological mechanisms. There is clearly an unmet need to develop novel strategies to maintain or restore microvascular perfusion in ACS patients, and these strategies require further investigation in large well-powered clinical trials with hard endpoints.

Author Contributions: Conceptualisation, K.V. and M.K.C.N.; original draft preparation, K.V.; figure design, B.T.; review and editing, S.P. and M.K.C.N. All authors have read and agreed to the published version of the manuscript.

Funding: This research received no external funding.

Conflicts of Interest: The authors declare no conflict of interest.

\section{References}

1. Niccoli, G.; Scalone, G.; Lerman, A.; Crea, F. Coronary microvascular obstruction in acute myocardial infarction. Eur. Heart J. 2016, 37, 1024-1033. [CrossRef] [PubMed]

2. Niccoli, G.; Montone, R.A.; Ibanez, B.; Thiele, H.; Crea, F.; Heusch, G.; Bulluck, H.; Hausenloy, D.J.; Berry, C.; Stiermaier, T.; et al. Optimized Treatment of ST-Elevation Myocardial Infarction. Circ. Res. 2019, 125, 245-258. [CrossRef] [PubMed]

3. Heusch, G. Coronary microvascular obstruction: The new frontier in cardioprotection. Basic Res. Cardiol. 2019, 114, 45. [CrossRef] [PubMed]

4. Pedersen, F.; Butrymovich, V.; Kelbæk, H.; Wachtell, K.; Helqvist, S.; Kastrup, J.; Holmvang, L.; Clemmensen, P.; Engstrøm, T.; Grande, P.; et al. Short- and Long-Term Cause of Death in Patients Treated With Primary PCI for STEMI. J. Am. Coll. Cardiol. 2014, 64, 2101-2108. [CrossRef] [PubMed]

5. Wu, K.C.; Zerhouni, E.A.; Judd, R.M.; Lugo-Olivieri, C.H.; Barouch, L.A.; Schulman, S.P.; Blumenthal, R.S.; Lima, J.A. Prognostic significance of microvascular obstruction by magnetic resonance imaging in patients with acute myocardial infarction. Circulation 1998, 97, 765-772. [CrossRef]

6. Carrick, D.; Haig, C.; Ahmed, N.; McEntegart, M.; Petrie, M.C.; Eteiba, H.; Hood, S.; Watkins, S.; Lindsay, M.M.; Davie, A.; et al. Myocardial Hemorrhage After Acute Reperfused ST-Segment-Elevation Myocardial Infarction: Relation to Microvascular Obstruction and Prognostic Significance. Circ. Cardiovasc. Imaging 2016, 9, e004148. [CrossRef] [PubMed]

7. de Waha, S.; Patel, M.R.; Granger, C.B.; Ohman, E.M.; Maehara, A.; Eitel, I.; Ben-Yehuda, O.; Jenkins, P.; Thiele, H.; Stone, G.W. Relationship between microvascular obstruction and adverse events following primary percutaneous coronary intervention for ST-segment elevation myocardial infarction: An individual patient data pooled analysis from seven randomized trials. Eur. Heart J. 2017, 38, 3502-3510. [CrossRef] [PubMed]

8. Fearon, W.F.; Low, A.F.; Yong, A.S.; McGeoch, R.; Berry, C.; Shah, M.G.; Ho, M.Y.; Kim, H.S.; Loh, J.P.; Oldroyd, K.G. Prognostic value of the Index of Microcirculatory Resistance measured after primary percutaneous coronary intervention. Circulation 2013, 127, 2436-2441. [CrossRef] 
9. Hamirani, Y.S.; Wong, A.; Kramer, C.M.; Salerno, M. Effect of microvascular obstruction and intramyocardial hemorrhage by CMR on LV remodeling and outcomes after myocardial infarction: A systematic review and meta-analysis. JACC Cardiovasc. Imaging 2014, 7, 940-952. [CrossRef]

10. Regenfus, M.; Schlundt, C.; Krähner, R.; Schönegger, C.; Adler, W.; Ludwig, J.; Daniel, W.G.; Schmid, M. Six-Year Prognostic Value of Microvascular Obstruction After Reperfused ST-Elevation Myocardial Infarction as Assessed by Contrast-Enhanced Cardiovascular Magnetic Resonance. Am. J. Cardiol. 2015, 116, 1022-1027. [CrossRef]

11. Stiermaier, T.; Thiele, H.; Eitel, I. Coronary Microvascular Obstruction: Key Factor in the Prognosis of ST-Segment-Elevation Myocardial Infarction. Circ. Cardiovasc. Imaging 2017, 10, e006568. [CrossRef] [PubMed]

12. Crea, F.; Camici, P.G.; Bairey Merz, C.N. Coronary microvascular dysfunction: An update. Eur. Heart J. 2014, $35,1101-1111$. [CrossRef]

13. Ong, P.; Athanasiadis, A.; Sechtem, U. Pharmacotherapy for coronary microvascular dysfunction. Eur. Heart J.-Cardiovasc. Pharmacother. 2015, 1, 65-71. [CrossRef]

14. Gibson, C.M.; Cannon, C.P.; Murphy, S.A.; Ryan, K.A.; Mesley, R.; Marble, S.J.; McCabe, C.H.; Van De Werf, F.; Braunwald, E. Relationship of TIMI myocardial perfusion grade to mortality after administration of thrombolytic drugs. Circulation 2000, 101, 125-130. [CrossRef]

15. Ng, M.K.; Yong, A.S.; Ho, M.; Shah, M.G.; Chawantanpipat, C.; O'Connell, R.; Keech, A.; Kritharides, L.; Fearon, W.F. The index of microcirculatory resistance predicts myocardial infarction related to percutaneous coronary intervention. Circ. Cardiovasc. Interv. 2012, 5, 515-522. [CrossRef]

16. Konijnenberg, L.S.F.; Damman, P.; Duncker, D.J.; Kloner, R.A.; Nijveldt, R.; van Geuns, R.M.; Berry, C.; Riksen, N.P.; Escaned, J.; van Royen, N. Pathophysiology and diagnosis of coronary microvascular dysfunction in ST-elevation myocardial infarction. Cardiovasc. Res. 2020, 116, 787-805. [CrossRef] [PubMed]

17. Di Carli, M.F.; Janisse, J.; Grunberger, G.; Ager, J. Role of chronic hyperglycemia in the pathogenesis of coronary microvascular dysfunction in diabetes. J. Am. Coll. Cardiol. 2003, 41, 1387-1393. [CrossRef]

18. Iwakura, K.; Ito, H.; Ikushima, M.; Kawano, S.; Okamura, A.; Asano, K.; Kuroda, T.; Tanaka, K.; Masuyama, T.; Hori, M.; et al. Association between hyperglycemia and the no-reflow phenomenon inpatients with acute myocardial infarction. J. Am. Coll. Cardiol. 2003, 41, 1-7. [CrossRef]

19. Hayakawa, H.; Raij, L. Relationship between hypercholesterolaemia, endothelial dysfunction and hypertension. J. Hypertens. 1999, 17, 611-619. [CrossRef]

20. Carrick, D.; Haig, C.; Ahmed, N.; Carberry, J.; Yue May, V.T.; McEntegart, M.; Petrie, M.C.; Eteiba, H.; Lindsay, M.; Hood, S.; et al. Comparative Prognostic Utility of Indexes of Microvascular Function Alone or in Combination in Patients With an Acute ST-Segment-Elevation Myocardial Infarction. Circulation 2016, 134, 1833-1847. [CrossRef]

21. Bulluck, H.; Rosmini, S.; Abdel-Gadir, A.; White, S.K.; Bhuva, A.N.; Treibel, T.A.; Fontana, M.; Ramlall, M.; Hamarneh, A.; Sirker, A.; et al. Residual Myocardial Iron Following Intramyocardial Hemorrhage During the Convalescent Phase of Reperfused ST-Segment-Elevation Myocardial Infarction and Adverse Left Ventricular Remodeling. Circ. Cardiovasc. Imaging 2016, 9 , e004940. [CrossRef]

22. Falk, E. Unstable angina with fatal outcome: Dynamic coronary thrombosis leading to infarction and/or sudden death. Autopsy evidence of recurrent mural thrombosis with peripheral embolization culminating in total vascular occlusion. Circulation 1985, 71, 699-708. [CrossRef] [PubMed]

23. Frink, R.J.; Rooney, P.A., Jr.; Trowbridge, J.O.; Rose, J.P. Coronary thrombosis and platelet/fibrin microemboli in death associated with acute myocardial infarction. Br. Heart J. 1988, 59, 196-200. [CrossRef]

24. Costa, R.A.; Abizaid, A.; Lotan, C.; Dudek, D.; Silber, S.; Dizon, J.M.; Maehara, A.; Dressler, O.; Brener, S.J.; Stone, G.W. Impact of thrombus burden on outcomes after standard versus mesh-covered stents in acute myocardial infarction (from the MGuard for acute ST elevation reperfusion trial). Am. J. Cardiol. 2015, 115, 161-166. [CrossRef] [PubMed]

25. Naruko, T.; Ueda, M.; Haze, K.; van der Wal, A.C.; van der Loos, C.M.; Itoh, A.; Komatsu, R.; Ikura, Y.; Ogami, M.; Shimada, Y.; et al. Neutrophil infiltration of culprit lesions in acute coronary syndromes. Circulation 2002, 106, 2894-2900. [CrossRef]

26. Vaidya, K.; Tucker, B.; Kurup, R.; Khandkar, C.; Pandzic, E.; Barraclough, J.; Machet, J.; Misra, A.; Kavurma, M.; Martinez, G.; et al. Colchicine Inhibits Neutrophil Extracellular Trap Formation in Patients With Acute Coronary Syndrome After Percutaneous Coronary Intervention. J. Am. Heart Assoc. 2021, 10, e018993. [CrossRef]

27. Carbone, F.; Nencioni, A.; Mach, F.; Vuilleumier, N.; Montecucco, F. Pathophysiological role of neutrophils in acute myocardial infarction. Thromb. Haemost. 2013, 110, 501-514. [CrossRef] [PubMed]

28. Mangold, A.; Alias, S.; Scherz, T.; Hofbauer, M.; Jakowitsch, J.; Panzenböck, A.; Simon, D.; Laimer, D.; Bangert, C.; Kammerlander, A.; et al. Coronary neutrophil extracellular trap burden and deoxyribonuclease activity in ST-elevation acute coronary syndrome are predictors of ST-segment resolution and infarct size. Circ. Res. 2015, 116, 1182-1192. [CrossRef]

29. Bonderman, D.; Teml, A.; Jakowitsch, J.; Adlbrecht, C.; Gyöngyösi, M.; Sperker, W.; Lass, H.; Mosgoeller, W.; Glogar, D.H.; Probst, P.; et al. Coronary no-reflow is caused by shedding of active tissue factor from dissected atherosclerotic plaque. Blood 2002, 99, 2794-2800. [CrossRef]

30. Seropian, I.M.; Toldo, S.; Van Tassell, B.W.; Abbate, A. Anti-inflammatory strategies for ventricular remodeling following ST-segment elevation acute myocardial infarction. J. Am. Coll. Cardiol. 2014, 63, 1593-1603. [CrossRef] 
31. Toldo, S.; Abbate, A. The NLRP3 inflammasome in acute myocardial infarction. Nat. Rev. Cardiol. 2018, 15, 203-214. [CrossRef]

32. Tiller, C.; Reindl, M.; Holzknecht, M.; Lechner, I.; Simma, F.; Schwaiger, J.; Mayr, A.; Klug, G.; Bauer, A.; Reinstadler, S.J.; et al. High sensitivity C-reactive protein is associated with worse infarct healing after revascularized ST-elevation myocardial infarction. Int. J. Cardiol. 2021, 328, 191-196. [CrossRef]

33. Tucker, B.; Vaidya, K.; Cochran, B.J.; Patel, S. Inflammation during Percutaneous Coronary Intervention-Prognostic Value, Mechanisms and Therapeutic Targets. Cells 2021, 10, 1391. [CrossRef]

34. Montone, R.A.; La Vecchia, G. Interplay between inflammation and microvascular obstruction in ST-segment elevation myocardial infarction: The importance of velocity. Int. J. Cardiol. 2021. [CrossRef]

35. Mayr, A.; Klug, G.; Schocke, M.; Trieb, T.; Mair, J.; Pedarnig, K.; Pachinger, O.; Jaschke, W.; Metzler, B. Late microvascular obstruction after acute myocardial infarction: Relation with cardiac and inflammatory markers. Int. J. Cardiol. 2012, 157, 391-396. [CrossRef]

36. Swiatkiewicz, I.; Kozinski, M.; Magielski, P.; Fabiszak, T.; Sukiennik, A.; Navarese, E.P.; Odrowaz-Sypniewska, G.; Kubica, J. Value of C-reactive protein in predicting left ventricular remodelling in patients with a first ST-segment elevation myocardial infarction. Mediat. Inflamm. 2012, 2012, 250867. [CrossRef]

37. Świątkiewicz, I.; Magielski, P.; Kubica, J. C-Reactive Protein as a Risk Marker for Post-Infarct Heart Failure over a Multi-Year Period. Int. J. Mol. Sci. 2021, 22, 3169. [CrossRef]

38. Świątkiewicz, I.; Magielski, P.; Kubica, J.; Zadourian, A.; DeMaria, A.N.; Taub, P.R. Enhanced Inflammation is a Marker for Risk of Post-Infarct Ventricular Dysfunction and Heart Failure. Int. J. Mol. Sci. 2020, 21, 807. [CrossRef]

39. Ørn, S.; Manhenke, C.; Ueland, T.; Damås, J.K.; Mollnes, T.E.; Edvardsen, T.; Aukrust, P.; Dickstein, K. C-reactive protein, infarct size, microvascular obstruction, and left-ventricular remodelling following acute myocardial infarction. Eur. Heart J. 2009, 30, 1180-1186. [CrossRef]

40. Holzknecht, M.; Tiller, C.; Reindl, M.; Lechner, I.; Troger, F.; Hosp, M.; Mayr, A.; Brenner, C.; Klug, G.; Bauer, A.; et al. C-reactive protein velocity predicts microvascular pathology after acute ST-elevation myocardial infarction. Int. J. Cardiol. 2021, 338, 30-36. [CrossRef]

41. Galiuto, L.; Gabrielli, F.A.; Lombardo, A.; La Torre, G.; Scarà, A.; Rebuzzi, A.G.; Crea, F. Reversible microvascular dysfunction coupled with persistent myocardial dysfunction: Implications for post-infarct left ventricular remodelling. Heart 2007, 93, 565-571. [CrossRef]

42. Guerra, E.; Hadamitzky, M.; Ndrepepa, G.; Bauer, C.; Ibrahim, T.; Ott, I.; Laugwitz, K.L.; Schunkert, H.; Kastrati, A. Microvascular obstruction in patients with non-ST-elevation myocardial infarction: A contrast-enhanced cardiac magnetic resonance study. Int. J. Cardiovasc. Imaging 2014, 30, 1087-1095. [CrossRef]

43. Nijveldt, R.; Beek, A.M.; Hirsch, A.; Stoel, M.G.; Hofman, M.B.; Umans, V.A.; Algra, P.R.; Twisk, J.W.; van Rossum, A.C. Functional recovery after acute myocardial infarction: Comparison between angiography, electrocardiography, and cardiovascular magnetic resonance measures of microvascular injury. J. Am. Coll. Cardiol. 2008, 52, 181-189. [CrossRef]

44. van 't Hof, A.W.; Liem, A.; Suryapranata, H.; Hoorntje, J.C.; de Boer, M.J.; Zijlstra, F. Angiographic assessment of myocardial reperfusion in patients treated with primary angioplasty for acute myocardial infarction: Myocardial blush grade. Zwolle Myocardial Infarction Study Group. Circulation 1998, 97, 2302-2306. [CrossRef]

45. Marra, M.P.; Corbetti, F.; Cacciavillani, L.; Tarantini, G.; Ramondo, A.B.; Napodano, M.; Basso, C.; Lacognata, C.; Marzari, A.; Maddalena, F; et al. Relationship between myocardial blush grades, staining, and severe microvascular damage after primary percutaneous coronary intervention a study performed with contrast-enhanced magnetic resonance in a large consecutive series of patients. Am. Heart J. 2010, 159, 1124-1132. [CrossRef]

46. Martínez, G.J.; Yong, A.S.; Fearon, W.F.; Ng, M.K. The index of microcirculatory resistance in the physiologic assessment of the coronary microcirculation. Coron. Artery Dis. 2015, 26 (Suppl. S1), e15-e26. [CrossRef]

47. Carrick, D.; Haig, C.; Carberry, J.; May, V.T.Y.; McCartney, P.; Welsh, P.; Ahmed, N.; McEntegart, M.; Petrie, M.C.; Eteiba, H.; et al. Microvascular resistance of the culprit coronary artery in acute ST-elevation myocardial infarction. JCI Insight 2016, 1, e85768. [CrossRef]

48. Ng, M.K.; Yeung, A.C.; Fearon, W.F. Invasive assessment of the coronary microcirculation: Superior reproducibility and less hemodynamic dependence of index of microcirculatory resistance compared with coronary flow reserve. Circulation 2006, 113, 2054-2061. [CrossRef]

49. Fearon, W.F.; Balsam, L.B.; Farouque, H.M.O.; Robbins, R.C.; Fitzgerald, P.J.; Yock, P.G.; Yeung, A.C. Novel Index for Invasively Assessing the Coronary Microcirculation. Circulation 2003, 107, 3129-3132. [CrossRef]

50. Fearon, W.F.; Shah, M.; Ng, M.; Brinton, T.; Wilson, A.; Tremmel, J.A.; Schnittger, I.; Lee, D.P.; Vagelos, R.H.; Fitzgerald, P.J.; et al. Predictive Value of the Index of Microcirculatory Resistance in Patients With ST-Segment Elevation Myocardial Infarction. J. Am. Coll. Cardiol. 2008, 51, 560-565. [CrossRef]

51. Bulluck, H.; Foin, N.; Cabrera-Fuentes, H.A.; Yeo, K.K.; Wong, A.S.; Fam, J.M.; Wong, P.E.; Tan, J.W.; Low, A.F.; Hausenloy, D.J. Index of Microvascular Resistance and Microvascular Obstruction in Patients With Acute Myocardial Infarction. JACC Cardiovasc. Interv. 2016, 9, 2172-2174. [CrossRef]

52. McGeoch, R.; Watkins, S.; Berry, C.; Steedman, T.; Davie, A.; Byrne, J.; Hillis, S.; Lindsay, M.; Robb, S.; Dargie, H.; et al. The index of microcirculatory resistance measured acutely predicts the extent and severity of myocardial infarction in patients with ST-segment elevation myocardial infarction. JACC Cardiovasc. Interv. 2010, 3, 715-722. [CrossRef] 
53. Payne, A.R.; Berry, C.; Doolin, O.; McEntegart, M.; Petrie, M.C.; Lindsay, M.M.; Hood, S.; Carrick, D.; Tzemos, N.; Weale, P.; et al. Microvascular Resistance Predicts Myocardial Salvage and Infarct Characteristics in ST-Elevation Myocardial Infarction. J. Am. Heart Assoc. 2012, 1, e002246. [CrossRef]

54. Hoef, T.P.v.d.; Bax, M.; Meuwissen, M.; Damman, P.; Delewi, R.; Winter, R.J.d.; Koch, K.T.; Schotborgh, C.; Henriques, J.P.S.; Tijssen, J.G.P.; et al. Impact of Coronary Microvascular Function on Long-term Cardiac Mortality in Patients With Acute ST-Segment-Elevation Myocardial Infarction. Circ. Cardiovasc. Interv. 2013, 6, 207-215. [CrossRef]

55. Jin, X.; Yoon, M.-H.; Seo, K.-W.; Tahk, S.-J.; Lim, H.-S.; Yang, H.-M.; Choi, B.-J.; Choi, S.-Y.; Hwang, G.-S.; Shin, J.-H.; et al. Usefulness of Hyperemic Microvascular Resistance Index as a Predictor of Clinical Outcomes in Patients with ST-Segment Elevation Myocardial Infarction. Korean Circ. J. 2015, 45, 194-201. [CrossRef]

56. Balian, V.; Galli, M.; Repetto, S.; Luvini, M.; Galdangelo, F.; Castiglioni, B.; Boscarini, M.; Petrucci, E.; Filippini, G.; Marcassa, C. Intracoronary ST segment evolution during primary coronary stenting predicts infarct zone recovery. Catheter. Cardiovasc. Interv. 2005, 64, 53-60. [CrossRef]

57. Wong, D.T.; Leung, M.C.; Das, R.; Liew, G.Y.; Teo, K.S.; Chew, D.P.; Meredith, I.T.; Worthley, M.I.; Worthley, S.G. Intracoronary ECG during primary percutaneous coronary intervention for ST-segment elevation myocardial infarction predicts microvascular obstruction and infarct size. Int. J. Cardiol. 2013, 165, 61-66. [CrossRef]

58. Schröder, R. Prognostic Impact of Early ST-Segment Resolution in Acute ST-Elevation Myocardial Infarction. Circulation 2004, 110, e506-e510. [CrossRef] [PubMed]

59. Tonet, E.; Pompei, G.; Faragasso, E.; Cossu, A.; Pavasini, R.; Passarini, G.; Tebaldi, M.; Campo, G. Coronary Microvascular Dysfunction: PET, CMR and CT Assessment. J. Clin. Med. 2021, 10, 1848. [CrossRef]

60. Feher, A.; Sinusas, A.J. Quantitative Assessment of Coronary Microvascular Function: Dynamic Single-Photon Emission Computed Tomography, Positron Emission Tomography, Ultrasound, Computed Tomography, and Magnetic Resonance Imaging. Circ. Cardiovasc. Imaging 2017, 10, e006427. [CrossRef]

61. Lautamäki, R.; Schuleri, K.H.; Sasano, T.; Javadi, M.S.; Youssef, A.; Merrill, J.; Nekolla, S.G.; Abraham, M.R.; Lardo, A.C.; Bengel, F.M. Integration of infarct size, tissue perfusion, and metabolism by hybrid cardiac positron emission tomography/computed tomography: Evaluation in a porcine model of myocardial infarction. Circ. Cardiovasc. Imaging 2009, 2, 299-305. [CrossRef]

62. Bulluck, H.; Dharmakumar, R.; Arai, A.E.; Berry, C.; Hausenloy, D.J. Cardiovascular Magnetic Resonance in Acute ST-SegmentElevation Myocardial Infarction: Recent Advances, Controversies, and Future Directions. Circulation 2018, 137, $1949-1964$. [CrossRef] [PubMed]

63. Nijveldt, R.; Hofman, M.B.; Hirsch, A.; Beek, A.M.; Umans, V.A.; Algra, P.R.; Piek, J.J.; van Rossum, A.C. Assessment of microvascular obstruction and prediction of short-term remodeling after acute myocardial infarction: Cardiac MR imaging study. Radiology 2009, 250, 363-370. [CrossRef]

64. Ibanez, B.; Prat-González, S.; Speidl, W.S.; Vilahur, G.; Pinero, A.; Cimmino, G.; García, M.J.; Fuster, V.; Sanz, J.; Badimon, J.J. Early metoprolol administration before coronary reperfusion results in increased myocardial salvage: Analysis of ischemic myocardium at risk using cardiac magnetic resonance. Circulation 2007, 115, 2909-2916. [CrossRef] [PubMed]

65. Pizarro, G.; Fernández-Friera, L.; Fuster, V.; Fernández-Jiménez, R.; García-Ruiz, J.M.; García-Álvarez, A.; Mateos, A.; Barreiro, M.V.; Escalera, N.; Rodriguez, M.D.; et al. Long-term benefit of early pre-reperfusion metoprolol administration in patients with acute myocardial infarction: Results from the METOCARD-CNIC trial (Effect of Metoprolol in Cardioprotection During an Acute Myocardial Infarction). J. Am. Coll. Cardiol. 2014, 63, 2356-2362. [CrossRef] [PubMed]

66. García-Prieto, J.; Villena-Gutiérrez, R.; Gómez, M.; Bernardo, E.; Pun-García, A.; García-Lunar, I.; Crainiciuc, G.; FernándezJiménez, R.; Sreeramkumar, V.; Bourio-Martínez, R.; et al. Neutrophil stunning by metoprolol reduces infarct size. Nat. Commun. 2017, 8, 14780. [CrossRef]

67. Roolvink, V.; Ibáñez, B.; Ottervanger, J.P.; Pizarro, G.; van Royen, N.; Mateos, A.; Dambrink, J.E.; Escalera, N.; Lipsic, E.; Albarran, A.; et al. Early Intravenous Beta-Blockers in Patients With ST-Segment Elevation Myocardial Infarction Before Primary Percutaneous Coronary Intervention. J. Am. Coll. Cardiol. 2016, 67, 2705-2715. [CrossRef]

68. Iwakura, K.; Ito, H.; Kawano, S.; Okamura, A.; Kurotobi, T.; Date, M.; Inoue, K.; Fujii, K. Chronic pre-treatment of statins is associated with the reduction of the no-reflow phenomenon in the patients with reperfused acute myocardial infarction. Eur. Heart J. 2006, 27, 534-539. [CrossRef]

69. Kim, J.S.; Kim, J.; Choi, D.; Lee, C.J.; Lee, S.H.; Ko, Y.G.; Hong, M.K.; Kim, B.K.; Oh, S.J.; Jeon, D.W.; et al. Efficacy of high-dose atorvastatin loading before primary percutaneous coronary intervention in ST-segment elevation myocardial infarction: The STATIN STEMI trial. JACC Cardiovasc. Interv. 2010, 3, 332-339. [CrossRef]

70. Hahn, J.Y.; Kim, H.J.; Choi, Y.J.; Jo, S.H.; Kim, H.J.; Lee, S.; Ahn, K.J.; Song, Y.B.; Choi, J.H.; Choi, S.H.; et al. Effects of atorvastatin pretreatment on infarct size in patients with ST-segment elevation myocardial infarction undergoing primary percutaneous coronary intervention. Am. Heart J. 2011, 162, 1026-1033. [CrossRef]

71. Cohen, M.V.; Downey, J.M. Adenosine: Trigger and mediator of cardioprotection. Basic Res. Cardiol. 2008, 103, 203-215. [CrossRef] [PubMed]

72. Kloner, R.A.; Forman, M.B.; Gibbons, R.J.; Ross, A.M.; Alexander, R.W.; Stone, G.W. Impact of time to therapy and reperfusion modality on the efficacy of adenosine in acute myocardial infarction: The AMISTAD-2 trial. Eur. Heart J. 2006, 27, $2400-2405$. [CrossRef] 
73. Ross, A.M.; Gibbons, R.J.; Stone, G.W.; Kloner, R.A.; Alexander, R.W. A randomized, double-blinded, placebo-controlled multicenter trial of adenosine as an adjunct to reperfusion in the treatment of acute myocardial infarction (AMISTAD-II). J. Am. Coll. Cardiol. 2005, 45, 1775-1780. [CrossRef]

74. Niccoli, G.; Rigattieri, S.; De Vita, M.R.; Valgimigli, M.; Corvo, P.; Fabbiocchi, F.; Romagnoli, E.; De Caterina, A.R.; La Torre, G.; Lo Schiavo, P.; et al. Open-label, randomized, placebo-controlled evaluation of intracoronary adenosine or nitroprusside after thrombus aspiration during primary percutaneous coronary intervention for the prevention of microvascular obstruction in acute myocardial infarction: The REOPEN-AMI study (Intracoronary Nitroprusside Versus Adenosine in Acute Myocardial Infarction). JACC Cardiovasc. Interv. 2013, 6, 580-589.

75. Niccoli, G.; Spaziani, C.; Crea, F. Left ventricular remodeling and 1-year clinical follow-up of the REOPEN-AMI trial. J. Am. Coll. Cardiol. 2014, 63, 1454-1455. [CrossRef]

76. Nazir, S.A.; McCann, G.P.; Greenwood, J.P.; Kunadian, V.; Khan, J.N.; Mahmoud, I.Z.; Blackman, D.J.; Been, M.; Abrams, K.R.; Shipley, L.; et al. Strategies to attenuate micro-vascular obstruction during P-PCI: The randomized reperfusion facilitated by local adjunctive therapy in ST-elevation myocardial infarction trial. Eur. Heart J. 2016, 37, 1910-1919. [CrossRef]

77. Kitakaze, M.; Asakura, M.; Kim, J.; Shintani, Y.; Asanuma, H.; Hamasaki, T.; Seguchi, O.; Myoishi, M.; Minamino, T.; Ohara, T.; et al. Human atrial natriuretic peptide and nicorandil as adjuncts to reperfusion treatment for acute myocardial infarction (J-WIND): Two randomised trials. Lancet 2007, 370, 1483-1493. [CrossRef]

78. Lønborg, J.; Vejlstrup, N.; Kelbæk, H.; Bøtker, H.E.; Kim, W.Y.; Mathiasen, A.B.; Jørgensen, E.; Helqvist, S.; Saunamäki, K.; Clemmensen, P.; et al. Exenatide reduces reperfusion injury in patients with ST-segment elevation myocardial infarction. Eur. Heart J. 2012, 33, 1491-1499. [CrossRef]

79. Woo, J.S.; Kim, W.; Ha, S.J.; Kim, J.B.; Kim, S.J.; Kim, W.S.; Seon, H.J.; Kim, K.S. Cardioprotective effects of exenatide in patients with ST-segment-elevation myocardial infarction undergoing primary percutaneous coronary intervention: Results of exenatide myocardial protection in revascularization study. Arterioscler. Thromb. Vasc. Biol. 2013, 33, 2252-2260. [CrossRef]

80. Roos, S.T.; Timmers, L.; Biesbroek, P.S.; Nijveldt, R.; Kamp, O.; van Rossum, A.C.; van Hout, G.P.J.; Stella, P.R.; Doevendans, P.A.; Knaapen, P.; et al. No benefit of additional treatment with exenatide in patients with an acute myocardial infarction. Int. J. Cardiol. 2016, 220, 809-814. [CrossRef]

81. Ibanez, B.; James, S.; Agewall, S.; Antunes, M.J.; Bucciarelli-Ducci, C.; Bueno, H.; Caforio, A.L.P.; Crea, F.; Goudevenos, J.A.; Halvorsen, S.; et al. 2017 ESC Guidelines for the management of acute myocardial infarction in patients presenting with STsegment elevation: The Task Force for the management of acute myocardial infarction in patients presenting with ST-segment elevation of the European Society of Cardiology (ESC). Eur. Heart J. 2017, 39, 119-177.

82. Ellis, S.G.; Tendera, M.; de Belder, M.A.; van Boven, A.J.; Widimsky, P.; Andersen, H.R.; Betriu, A.; Savonitto, S.; Adamus, J.; Peruga, J.Z.; et al. 1-year survival in a randomized trial of facilitated reperfusion: Results from the FINESSE (Facilitated Intervention with Enhanced Reperfusion Speed to Stop Events) trial. JACC Cardiovasc. Interv. 2009, 2, 909-916. [CrossRef]

83. Petronio, A.S.; De Carlo, M.; Strata, E.; Gistri, R.; Palmieri, C.; Aquaro, G.; Borelli, G.; Vaghetti, M.; Delle Donne, M.; Lombardi, M.; et al. Impact of early abciximab administration on infarct size in patients with ST-elevation myocardial infarction. Int. J. Cardiol. 2012, 155, 230-235. [CrossRef]

84. Maioli, M.; Bellandi, F.; Leoncini, M.; Toso, A.; Dabizzi, R.P. Randomized early versus late abciximab in acute myocardial infarction treated with primary coronary intervention (RELAx-AMI Trial). J. Am. Coll. Cardiol. 2007, 49, 1517-1524. [CrossRef]

85. Van't Hof, A.W.; Ten Berg, J.; Heestermans, T.; Dill, T.; Funck, R.C.; van Werkum, W.; Dambrink, J.H.; Suryapranata, H.; van Houwelingen, G.; Ottervanger, J.P.; et al. Prehospital initiation of tirofiban in patients with ST-elevation myocardial infarction undergoing primary angioplasty (On-TIME 2): A multicentre, double-blind, randomised controlled trial. Lancet 2008, 372, 537-546. [CrossRef]

86. Stone, G.W.; Maehara, A.; Witzenbichler, B.; Godlewski, J.; Parise, H.; Dambrink, J.H.; Ochala, A.; Carlton, T.W.; Cristea, E.; Wolff, S.D.; et al. Intracoronary abciximab and aspiration thrombectomy in patients with large anterior myocardial infarction: The INFUSE-AMI randomized trial. JAMA 2012, 307, 1817-1826. [CrossRef] [PubMed]

87. Thiele, H.; Wöhrle, J.; Hambrecht, R.; Rittger, H.; Birkemeyer, R.; Lauer, B.; Neuhaus, P.; Brosteanu, O.; Sick, P.; Wiemer, M.; et al. Intracoronary versus intravenous bolus abciximab during primary percutaneous coronary intervention in patients with acute ST-elevation myocardial infarction: A randomised trial. Lancet 2012, 379, 923-931. [CrossRef]

88. de Waha, S.; Eitel, I.; Desch, S.; Fuernau, G.; Lurz, P.; Schuler, G.; Thiele, H. Association of upstream clopidogrel administration and myocardial reperfusion assessed by cardiac magnetic resonance imaging in patients with ST-elevation myocardial infarction. Eur. Heart J. Acute Cardiovasc. Care 2014, 3, 110-117. [CrossRef] [PubMed]

89. Kunadian, V.; James, S.K.; Wojdyla, D.M.; Zorkun, C.; Wu, J.; Storey, R.F.; Steg, P.G.; Katus, H.; Emanuelsson, H.; Horrow, J.; et al. Angiographic outcomes in the PLATO Trial (Platelet Inhibition and Patient Outcomes). JACC Cardiovasc. Interv. 2013, 6, 671-683. [CrossRef] [PubMed]

90. Montalescot, G.; van 't Hof, A.W.; Lapostolle, F.; Silvain, J.; Lassen, J.F.; Bolognese, L.; Cantor, W.J.; Cequier, Á.; Chettibi, M.; Goodman, S.G.; et al. Prehospital Ticagrelor in ST-Segment Elevation Myocardial Infarction. N. Engl. J. Med. 2014, 371, $1016-1027$. [CrossRef]

91. van Leeuwen, M.A.H.; van der Hoeven, N.W.; Janssens, G.N.; Everaars, H.; Nap, A.; Lemkes, J.S.; de Waard, G.A.; van de Ven, P.M.; van Rossum, A.C.; Ten Cate, T.J.F.; et al. Evaluation of Microvascular Injury in Revascularized Patients With ST-Segment-Elevation Myocardial Infarction Treated With Ticagrelor Versus Prasugrel. Circulation 2019, 139, 636-646. [CrossRef] 
92. Bulluck, H.; Chan, M.H.H.; Bryant, J.A.; Chai, P.; Chawla, A.; Chua, T.S.; Chung, Y.C.; Fei, G.; Ho, H.H.; Ho, A.F.W.; et al. Platelet inhibition to target reperfusion injury trial: Rationale and study design. Clin. Cardiol. 2019, 42, 5-12. [CrossRef] [PubMed]

93. Lønborg, J.; Holmvang, L.; Kelbæk, H.; Vejlstrup, N.; Jørgensen, E.; Helqvist, S.; Saunamäki, K.; Clemmensen, P.; Treiman, M.; Jensen, J.S.; et al. ST-Segment resolution and clinical outcome with ischemic postconditioning and comparison to magnetic resonance. Am. Heart J. 2010, 160, 1085-1091. [CrossRef] [PubMed]

94. Traverse, J.H.; Swingen, C.M.; Henry, T.D.; Fox, J.; Wang, Y.L.; Chavez, I.J.; Lips, D.L.; Lesser, J.R.; Pedersen, W.R.; Burke, N.M.; et al. NHLBI-Sponsored Randomized Trial of Postconditioning During Primary Percutaneous Coronary Intervention for ST-Elevation Myocardial Infarction. Circ. Res. 2019, 124, 769-778. [CrossRef]

95. Hahn, J.Y.; Song, Y.B.; Kim, E.K.; Yu, C.W.; Bae, J.W.; Chung, W.Y.; Choi, S.H.; Choi, J.H.; Bae, J.H.; An, K.J.; et al. Ischemic postconditioning during primary percutaneous coronary intervention: The effects of postconditioning on myocardial reperfusion in patients with ST-segment elevation myocardial infarction (POST) randomized trial. Circulation 2013, 128, 1889-1896. [CrossRef] [PubMed]

96. Engstrøm, T.; Kelbæk, H.; Helqvist, S.; Høfsten, D.E.; Kløvgaard, L.; Clemmensen, P.; Holmvang, L.; Jørgensen, E.; Pedersen, F.; Saunamaki, K.; et al. Effect of Ischemic Postconditioning During Primary Percutaneous Coronary Intervention for Patients With ST-Segment Elevation Myocardial Infarction: A Randomized Clinical Trial. JAMA Cardiol. 2017, 2, 490-497. [CrossRef] [PubMed]

97. Bøtker, H.E.; Kharbanda, R.; Schmidt, M.R.; Bøttcher, M.; Kaltoft, A.K.; Terkelsen, C.J.; Munk, K.; Andersen, N.H.; Hansen, T.M.; Trautner, S.; et al. Remote ischaemic conditioning before hospital admission, as a complement to angioplasty, and effect on myocardial salvage in patients with acute myocardial infarction: A randomised trial. Lancet 2010, 375, 727-734. [CrossRef]

98. Crimi, G.; Pica, S.; Raineri, C.; Bramucci, E.; De Ferrari, G.M.; Klersy, C.; Ferlini, M.; Marinoni, B.; Repetto, A.; Romeo, M.; et al. Remote ischemic post-conditioning of the lower limb during primary percutaneous coronary intervention safely reduces enzymatic infarct size in anterior myocardial infarction: A randomized controlled trial. JACC Cardiovasc. Interv. 2013, 6, 1055-1063. [CrossRef]

99. White, S.K.; Frohlich, G.M.; Sado, D.M.; Maestrini, V.; Fontana, M.; Treibel, T.A.; Tehrani, S.; Flett, A.S.; Meier, P.; Ariti, C.; et al. Remote ischemic conditioning reduces myocardial infarct size and edema in patients with ST-segment elevation myocardial infarction. JACC Cardiovasc. Interv. 2015, 8, 178-188. [CrossRef]

100. Eitel, I.; Stiermaier, T.; Rommel, K.P.; Fuernau, G.; Sandri, M.; Mangner, N.; Linke, A.; Erbs, S.; Lurz, P.; Boudriot, E.; et al. Cardioprotection by combined intrahospital remote ischaemic perconditioning and postconditioning in ST-elevation myocardial infarction: The randomized LIPSIA CONDITIONING trial. Eur. Heart J. 2015, 36, 3049-3057. [CrossRef]

101. Stiermaier, T.; Jensen, J.O.; Rommel, K.P.; de Waha-Thiele, S.; Fuernau, G.; Desch, S.; Thiele, H.; Eitel, I. Combined Intrahospital Remote Ischemic Perconditioning and Postconditioning Improves Clinical Outcome in ST-Elevation Myocardial Infarction. Circ. Res. 2019, 124, 1482-1491. [CrossRef]

102. Hausenloy, D.J.; Kharbanda, R.K.; Møller, U.K.; Ramlall, M.; Aarøe, J.; Butler, R.; Bulluck, H.; Clayton, T.; Dana, A.; Dodd, M.; et al. Effect of remote ischaemic conditioning on clinical outcomes in patients with acute myocardial infarction (CONDI-2/ERIC-PPCI): A single-blind randomised controlled trial. Lancet 2019, 394, 1415-1424. [CrossRef]

103. Burzotta, F.; Trani, C.; Romagnoli, E.; Mazzari, M.A.; Rebuzzi, A.G.; De Vita, M.; Garramone, B.; Giannico, F.; Niccoli, G.; Biondi-Zoccai, G.G.; et al. Manual thrombus-aspiration improves myocardial reperfusion: The randomized evaluation of the effect of mechanical reduction of distal embolization by thrombus-aspiration in primary and rescue angioplasty (REMEDIA) trial. J. Am. Coll. Cardiol. 2005, 46, 371-376. [CrossRef] [PubMed]

104. Svilaas, T.; Vlaar, P.J.; van der Horst, I.C.; Diercks, G.F.H.; de Smet, B.J.G.L.; van den Heuvel, A.F.M.; Anthonio, R.L.; Jessurun, G.A.; Tan, E.-S.; Suurmeijer, A.J.H.; et al. Thrombus Aspiration during Primary Percutaneous Coronary Intervention. N. Engl. J. Med. 2008, 358, 557-567. [CrossRef] [PubMed]

105. Vlaar, P.J.; Svilaas, T.; van der Horst, I.C.; Diercks, G.F.; Fokkema, M.L.; de Smet, B.J.; van den Heuvel, A.F.; Anthonio, R.L.; Jessurun, G.A.; Tan, E.S.; et al. Cardiac death and reinfarction after 1 year in the Thrombus Aspiration during Percutaneous coronary intervention in Acute myocardial infarction Study (TAPAS): A 1-year follow-up study. Lancet 2008, 371, 1915-1920. [CrossRef]

106. De Luca, G.; Dudek, D.; Sardella, G.; Marino, P.; Chevalier, B.; Zijlstra, F. Adjunctive manual thrombectomy improves myocardial perfusion and mortality in patients undergoing primary percutaneous coronary intervention for ST-elevation myocardial infarction: A meta-analysis of randomized trials. Eur. Heart J. 2008, 29, 3002-3010. [CrossRef]

107. Fröbert, O.; Lagerqvist, B.; Olivecrona, G.K.; Omerovic, E.; Gudnason, T.; Maeng, M.; Aasa, M.; Angerås, O.; Calais, F.; Danielewicz, M.; et al. Thrombus aspiration during ST-segment elevation myocardial infarction. N. Engl. J. Med. 2013, 369, 1587-1597. [CrossRef]

108. Lagerqvist, B.; Fröbert, O.; Olivecrona, G.K.; Gudnason, T.; Maeng, M.; Alström, P.; Andersson, J.; Calais, F.; Carlsson, J.; Collste, O.; et al. Outcomes 1 year after thrombus aspiration for myocardial infarction. N. Engl. J. Med. 2014, 371, 1111-1120. [CrossRef]

109. Jolly, S.S.; Cairns, J.A.; Yusuf, S.; Meeks, B.; Pogue, J.; Rokoss, M.J.; Kedev, S.; Thabane, L.; Stankovic, G.; Moreno, R.; et al. Randomized Trial of Primary PCI with or without Routine Manual Thrombectomy. N. Engl. J. Med. 2015, 372, 1389-1398. [CrossRef] 
110. Migliorini, A.; Stabile, A.; Rodriguez, A.E.; Gandolfo, C.; Rodriguez Granillo, A.M.; Valenti, R.; Parodi, G.; Neumann, F.J.; Colombo, A.; Antoniucci, D. Comparison of AngioJet rheolytic thrombectomy before direct infarct artery stenting with direct stenting alone in patients with acute myocardial infarction: The JETSTENT trial. J. Am. Coll. Cardiol. 2010, 56, 1298-1306. [CrossRef]

111. Stone, G.W.; Abizaid, A.; Silber, S.; Dizon, J.M.; Merkely, B.; Costa, R.A.; Kornowski, R.; Abizaid, A.; Wojdyła, R.; Maehara, A.; et al. Prospective, Randomized, Multicenter Evaluation of a Polyethylene Terephthalate Micronet Mesh-Covered Stent (MGuard) in ST-Segment Elevation Myocardial Infarction: The MASTER Trial. J. Am. Coll. Cardiol. 2012, 60, 1975-1984. [CrossRef] [PubMed]

112. Carrick, D.; Oldroyd, K.G.; McEntegart, M.; Haig, C.; Petrie, M.C.; Eteiba, H.; Hood, S.; Owens, C.; Watkins, S.; Layland, J.; et al. A randomized trial of deferred stenting versus immediate stenting to prevent no- or slow-reflow in acute ST-segment elevation myocardial infarction (DEFER-STEMI). J. Am. Coll. Cardiol. 2014, 63, 2088-2098. [CrossRef]

113. De Maria, G.L.; Alkhalil, M.; Borlotti, A.; Wolfrum, M.; Gaughran, L.; Dall'Armellina, E.; Langrish, J.P.; Lucking, A.J.; Choudhury, R.P.; Kharbanda, R.K.; et al. Index of microcirculatory resistance-guided therapy with pressure-controlled intermittent coronary sinus occlusion improves coronary microvascular function and reduces infarct size in patients with ST-elevation myocardial infarction: The Oxford Acute Myocardial Infarction-Pressure-controlled Intermittent Coronary Sinus Occlusion study (OxAMIPICSO study). EuroInterv. J. Eur. Collab. Work. Group Interv. Cardiol. Eur. Soc. Cardiol. 2018, 14, e352-e359.

114. Sezer, M.; Oflaz, H.; Gören, T.; Okçular, I.; Umman, B.; Nişanci, Y.; Bilge, A.K.; Şanli, Y.; Meriç, M.; Umman, S. Intracoronary Streptokinase after Primary Percutaneous Coronary Intervention. N. Engl. J. Med. 2007, 356, 1823-1834. [CrossRef]

115. Sezer, M.; Çimen, A.; Aslanger, E.; Elitok, A.; Umman, B.; Buğra, Z.; Yormaz, E.; Türkmen, C.; Adalet, I.Ş.; Nişanci, Y.; et al. Effect of Intracoronary Streptokinase Administered Immediately After Primary Percutaneous Coronary Intervention on Long-Term Left Ventricular Infarct Size, Volumes, and Function. J. Am. Coll. Cardiol. 2009, 54, 1065-1071. [CrossRef]

116. Morales-Ponce, F.J.; Lozano-Cid, F.J.; Martinez-Romero, P.; Gonzalez-Perez, P.; Sanchez-Brotons, J.A.; Diaz-Torres, I.; RodriguezYanez, J.C.; Caro-Mateo, P.; Serrador-Frutos, A.M. Intracoronary tenecteplase versus abciximab as adjunctive treatment during primary percutaneous coronary intervention in patients with anterior myocardial infarction. EuroInterv. J. Eur. Collab. Work. Group Interv. Cardiol. Eur. Soc. Cardiol. 2019, 14, 1668-1675. [CrossRef]

117. Morales-Ponce, F.J.; González-Pérez, P.; Blasco-Turrión, S.; Sánchez-Brotons, J.A.; Collado-Moreno, C.; Martínez-Romero, P.; Martínez-Morentín, E.; Caro-Mateo, P. Effects of intracoronary antithrombotics on ventricular function: A comparison of tenecteplase versus abciximab during primary percutaneous intervention in myocardial infarction. Cardiol. J. 2021, 28, 176-178. [CrossRef] [PubMed]

118. McCartney, P.J.; Eteiba, H.; Maznyczka, A.M.; McEntegart, M.; Greenwood, J.P.; Muir, D.F.; Chowdhary, S.; Gershlick, A.H.; Appleby, C.; Cotton, J.M.; et al. Effect of Low-Dose Intracoronary Alteplase During Primary Percutaneous Coronary Intervention on Microvascular Obstruction in Patients With Acute Myocardial Infarction: A Randomized Clinical Trial. JAMA 2019, 321, 56-68. [CrossRef] [PubMed]

119. Ge, L.; Zhou, X.; Ji, W.J.; Lu, R.Y.; Zhang, Y.; Zhang, Y.D.; Ma, Y.Q.; Zhao, J.H.; Li, Y.M. Neutrophil extracellular traps in ischemia-reperfusion injury-induced myocardial no-reflow: Therapeutic potential of DNase-based reperfusion strategy. Am. J. Physiol.-Heart Circ. Physiol. 2015, 308, H500-H509. [CrossRef]

120. Dirksen, M.T.; Laarman, G.; van 't Hof, A.W.; Guagliumi, G.; Tonino, W.A.; Tavazzi, L.; Duncker, D.J.; Simoons, M.L. The effect of ITF-1697 on reperfusion in patients undergoing primary angioplasty. Safety and efficacy of a novel tetrapeptide, ITF-1697. Eur. Heart J. 2004, 25, 392-400. [CrossRef] [PubMed]

121. Testa, L.; Van Gaal, W.J.; Bhindi, R.; Biondi-Zoccai, G.G.; Abbate, A.; Agostoni, P.; Porto, I.; Andreotti, F.; Crea, F.; Banning, A.P. Pexelizumab in ischemic heart disease: A systematic review and meta-analysis on 15,196 patients. J. Thorac. Cardiovasc. Surg. 2008, 136, 884-893. [CrossRef]

122. Atar, D.; Petzelbauer, P.; Schwitter, J.; Huber, K.; Rensing, B.; Kasprzak, J.D.; Butter, C.; Grip, L.; Hansen, P.R.; Süselbeck, T.; et al. Effect of intravenous FX06 as an adjunct to primary percutaneous coronary intervention for acute ST-segment elevation myocardial infarction results of the F.I.R.E. (Efficacy of FX06 in the Prevention of Myocardial Reperfusion Injury) trial. J. Am. Coll. Cardiol. 2009, 53, 720-729. [CrossRef]

123. Ridker, P.M.; Everett, B.M.; Thuren, T.; MacFadyen, J.G.; Chang, W.H.; Ballantyne, C.; Fonseca, F.; Nicolau, J.; Koenig, W.; Anker, S.D.; et al. Antiinflammatory Therapy with Canakinumab for Atherosclerotic Disease. N. Engl. J. Med. 2017, 377, 1119-1131. [CrossRef]

124. Everett, B.M.; Cornel, J.H.; Lainscak, M.; Anker, S.D.; Abbate, A.; Thuren, T.; Libby, P.; Glynn, R.J.; Ridker, P.M. Anti-Inflammatory Therapy With Canakinumab for the Prevention of Hospitalization for Heart Failure. Circulation 2019, 139, 1289-1299. [CrossRef] [PubMed]

125. Abbate, A.; Toldo, S.; Marchetti, C.; Kron, J.; Van Tassell, B.W.; Dinarello, C.A. Interleukin-1 and the Inflammasome as Therapeutic Targets in Cardiovascular Disease. Circ. Res. 2020, 126, 1260-1280. [CrossRef] [PubMed]

126. Abbate, A.; Trankle, C.R.; Buckley, L.F.; Lipinski, M.J.; Appleton, D.; Kadariya, D.; Canada, J.M.; Carbone, S.; Roberts, C.S.; Abouzaki, N.; et al. Interleukin-1 Blockade Inhibits the Acute Inflammatory Response in Patients With ST-Segment-Elevation Myocardial Infarction. J. Am. Heart Assoc. 2020, 9, e014941. [CrossRef] [PubMed] 
127. Erlinge, D.; Götberg, M.; Lang, I.; Holzer, M.; Noc, M.; Clemmensen, P.; Jensen, U.; Metzler, B.; James, S.; Bötker, H.E.; et al. Rapid endovascular catheter core cooling combined with cold saline as an adjunct to percutaneous coronary intervention for the treatment of acute myocardial infarction. The CHILL-MI trial: A randomized controlled study of the use of central venous catheter core cooling combined with cold saline as an adjunct to percutaneous coronary intervention for the treatment of acute myocardial infarction. J. Am. Coll. Cardiol. 2014, 63, 1857-1865. [PubMed]

128. Chan, W.; Taylor, A.J.; Ellims, A.H.; Lefkovits, L.; Wong, C.; Kingwell, B.A.; Natoli, A.; Croft, K.D.; Mori, T.; Kaye, D.M.; et al. Effect of iron chelation on myocardial infarct size and oxidative stress in ST-elevation-myocardial infarction. Circ. Cardiovasc. Interv. 2012, 5, 270-278. [CrossRef] [PubMed] 